\title{
Genotypic and environmental factors influence the proximate composition and quality attributes of sweetpotato (Ipomoea batatas L.)
}

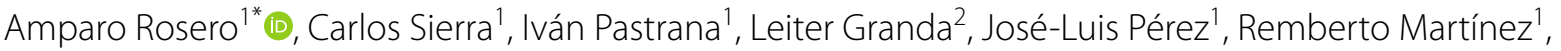 \\ Julio Morelo' ${ }^{1}$ Laura Espitia' ${ }^{1}$, Hernando Araujo ${ }^{1}$ and Claudia De Paula ${ }^{3}$
}

\begin{abstract}
Background: Sweetpotato is an important staple food crop worldwide. The genotype mainly influences the nutritional quality of its storage roots, but environmental conditions could produce significant variations in chemical composition and quality. The aim of this study was to characterize sweetpotato diversity of 20 selected genotypes and identify harvest time $(90,120$, and 150 days after planting-DAP) and environmental effects on quality attributes estimated by proximate analysis (dry matter, ash, crude fiber, total protein, and total soluble solids). Red (R), green (G), and blue (B) (RGB) analysis was used to characterize the genotypes phenotypically.

Results: The results of the current study revealed that flesh color was associated with proximate composition. RGB analysis showed that low B pixel values were present in yellow-orange- and purple-fleshed genotypes, which simultaneously exhibited high total protein content (TPC), ash content (AC), and crude fiber (CF), while cream- and white-fleshed genotypes showed high B pixel values and were related to high dry matter content (DMC). In these genotypes, the high DMC was maintained or increased through harvest time, however, a reduction in the proportion of accumulated AC and TPC was observed. On the other hand, in the pigmented genotypes, DMC increased up to 120 DAP, showing major stability in terms of AC and TPC. Regardless of harvest time, more intense rain events 30 days before harvest, affected the storage of DMC in roots negatively, while AC, TPC, and CF were accumulated more efficiently, or their proportion increased. High temperatures increased total soluble solids (TSS) accumulation and reduced AC, TPC, and CF accumulation. The combined analysis, according to the additive main effects and multiplicative interaction (AMMI) model, confirmed these results.

Conclusions: These findings indicated that white-fleshed genotypes contain high DMC, although, with lower TPC, $A C$, and CF contents compared to yellow-orange- and purple-fleshed genotypes. Although there is an increase in DMC in extended harvests (in orange-fleshed genotypes up to $120 \mathrm{DAP}$ ), the presence of pre-harvest rain promotes its translocation and loss. On the contrary, TPC, AC, and CF can be kept stable or even increase, except in environments with high temperatures that induce low accumulation. The current study provides a better understanding of the nutritional response of sweetpotato diversity under several growing conditions, which can be recognized and used integrally to improve food quality.
\end{abstract}

\footnotetext{
*Correspondence: erosero@agrosavia.co

${ }^{1}$ Corporación Colombiana de Investigación Agropecuaria - AGROSAVIA, Centro de Investigación Turipaná, Km 13 vía Montería, Cereté, Colombia

Full list of author information is available at the end of the article
}

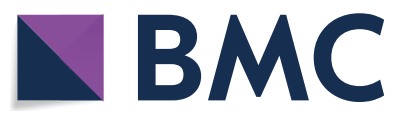

(c) The Author(s) 2020. This article is licensed under a Creative Commons Attribution 4.0 International License, which permits use, sharing, adaptation, distribution and reproduction in any medium or format, as long as you give appropriate credit to the original author(s) and the source, provide a link to the Creative Commons licence, and indicate if changes were made. The images or other third party material in this article are included in the article's Creative Commons licence, unless indicated otherwise in a credit line to the material. If material is not included in the article's Creative Commons licence and your intended use is not permitted by statutory regulation or exceeds the permitted use, you will need to obtain permission directly from the copyright holder. To view a copy of this licence, visit http://creativeco mmons.org/licenses/by/4.0/. The Creative Commons Public Domain Dedication waiver (http://creativecommons.org/publicdomain/ zero/1.0/) applies to the data made available in this article, unless otherwise stated in a credit line to the data. 
Keywords: Environmental conditions, Harvest time, Nutritional quality, Proximate composition, RGB image analysis, Sweetpotato

\section{Background}

Sweetpotato (Ipomoea batatas L.) is a worldwide important crop for human nutrition. The relevance of this crop is due to its nutritional quality, so its proximate composition is important to understand the role it plays in basic nutrition. Sweetpotato is rich in carbohydrates, being mainly starch, one of the most important energy sources for consumers. Ash directly denotes the mineral content (potassium, manganese, copper, iron and zinc), and proteins are nutrients that provide essential amino acids required for metabolism. Crude fiber is one of several nondigestible carbohydrates that benefit the intestinal tract. Total soluble solids influence the taste and overall sensory acceptability of food, and some genotypes are rich in provitamin $\mathrm{A}$ ( $\beta$-carotene) and vitamins $\mathrm{B} 1, \mathrm{~B} 3$, $C$, and $E[2,30]$. Furthermore, sweetpotato has a high potential for industrial processes (starch and flour extraction), such as the manufacture of noodles and compotes, the elaboration of processed products (juice and croquettes), and the preparation of low-fat baked snacks as a substitute for flours in the bakery industry. In general, it is considered as an ingredient in the preparation of functional foods due to its high content of dietary fiber and digestion-resistant starch $[9,36,41,44]$.

The formation of storage roots in sweetpotato is a complex process that involves: (i) stopping root elongation; (ii) initiation of the vascular cambium, and (iii) increasing radial growth through cell-proliferation and expansion [40]. Therefore, harvest delay may affect the storage root quality [38]. Sweetpotato is a drought-tolerant crop with high dry matter content (DMC) that is the main characteristic considered by consumers and processors [25]. Nonetheless, not only its storage roots can be consumed, but also its leaves. The flesh of the storage roots can have a white, cream, yellow, orange, or purple color. According to the characteristics of the root flesh, there are three main groups of cultivars: (i) cultivars with very high DMC and starch $(\approx 25-35 \%)$ that generally have a white or cream color in their flesh, and used for processing (traditional or industrial); (ii) cultivars with high DMC $(\approx 20-30 \%)$, low sugar content and high provitamin $\mathrm{A}$ carotenoids, used for fresh root consumption [23, 48], and (iii) cultivars with low DMC and high sugar and carotene contents; deep orange-fleshed for export markets, mainly to the U.S. [23]. However, there are different factors affecting DMC in sweetpotato, including the cultivar (genotype), geographic area, light amount [20, 25, 48, 53], climate, cultural practices and soil types. Incidence of pests and diseases through physiological alterations that affect its production and partitioning [3, 40, 42], crop age [43], and storage [56, 29]. Studies have reported a wide variability for DMC in sweetpotato cultivars based on the study of different populations (genotype collections), showing a range between $24.3 \%$ and $51.1 \%$ [ 48 , $56,54]$. Varieties with high dry matter content show values higher than $30 \%[4,7,47]$. Orange-fleshed genotypes generally exhibit lower dry matter contents $(<30 \%)[7,14$, 47,49 , while purple varieties maintain a similar range $(21-33 \%)[17,28]$. Similarly, several reports showed the effects of crop seasons and agroecological conditions on DMC of sweetpotato storage roots. In India, the crop season influenced the DMC significantly in selected genotypes showing a range from $14.0 \%$ to $37 \%$ [29]; the influence of three different agroecological zones in Malawi produced significant differences in DMC, reporting a range of $26.8 \%$ to $34.4 \%$ [20]; furthermore, under West Bengal conditions, values of 18.42 to $31.62 \%$ for different genotypes were found [33].

The mineral content in the soil affects iron and zinc variations in crops [38], just as variations in ash content influence sweetpotato root flesh color. Caetano et al. [8] reported values with an average of $1.0 \%$ of ash content $(\mathrm{AC})$ in sweetpotato with different flesh colors, suggesting that the genotype does not affect this variable. However, significant differences among sweetpotato cultivars have been reported, showing ash content between 0.6 and $1.0 \%$ [15].

The protein content (PC) of sweetpotato varies and is influenced by the cultivar, location, soil fertility, and infestation by pests and diseases [4]. Further, a range of 1.60 to $9.50 \%$ of PC for sweetpotato cultivars from different origins and cultivated under several environmental conditions has been reported by various authors $[18$, $48,54]$. Nevertheless, adequate nitrogen availability has a significant increase in PC, indicating that nitrogen is an important factor in determining the yield and nutrient composition of storage roots [50].

Several studies show that crude fiber (CF) content varies from one variety to another [10]. Based on dry weight, CF values ranged between $1.8 \%$ and $2.8 \%$ depending on the cultivar and the type of nitrogen fertilization [50]. Moreover, CF is affected by the processing method and its interaction with the cultivars [10].

Total soluble solids (TSS) content is an important quality parameter that determines the quality of the processed food product [33]. Various studies revealed that 
TSS varied from 7.30 to $14.57^{\circ}$ Brix in fresh sweetpotato storage roots, depending on skin and flesh colors $[8,23$, $33,51]$. The maturity stage and edaphoclimatic conditions also influence TSS, which is also related to the DMC [23].

DMC, ash, protein, CF, and TSS are features in sweetpotato storage roots that directly influence its quality for direct consumption or processing. The high content of protein and ash ensures better nutritional quality in storage roots that are mainly sources of carbohydrates. Accordingly, the aim of this work was to identify the genotypes and environmental conditions that improve the quality attributes of sweetpotato. A cost-effective process was included, red $(R)$, green $(G)$ and blue (B) (RGB) image analysis, to characterize quality attributes of sweetpotato. The high nutritional quality diversity in sweetpotato represents a valuable potential for fulfilling nutritional requirements; however, a cropping system could contribute to ensure simultaneously good yield and quality.

\section{Results}

\section{Root flesh color reflects the proximate composition diversity in sweet potato}

The combination of RGB image analysis as a phenotyping tool and a proximate analysis produces efficient dissection of sweetpotato diversity in food quality. Phenotypic characterization using RGB image analysis of transversal cuts of storage roots was used to obtain mean red $(R)$, green $(G)$, and blue (B) pixel values (Table 1). Cluster analysis using $\mathrm{R}, \mathrm{G}$, and $\mathrm{B}$ pixel values produced a hierarchy of three groups clustered mainly due to mean $\mathrm{G}$ pixel values. The first group (G1) included values that ranged from 163 to 195.9 in white-cream fleshed genotypes, the second group (G2) showed values from 121.2 to 179.3 in yellow-orange genotypes, and the third group (G3), contained values that ranged from 49.5 to 97.8 in genotypes with purple flesh (Fig. 1a; Table 1). Similarly, B pixel values were higher in white-cream fleshed genotypes showing a range of 129 to 155.2 , while genotypes with pigmented flesh showed a range of 56.1 to 104.4. Regarding $\mathrm{R}$ pixel values, white-to-orange flesh genotypes showed a range of 181.8 to 206.6 , and purple genotypes showed values between 115.3 and 141.5. The color descriptions detected differences among groups, results that were consistently confirmed by the Tukey test (Table 1).

Similar clustering was obtained when DMC, TPC, $\mathrm{AC}, \mathrm{CF}$, and TSS were included in the hierarchical cluster analysis (Fig. 1b). The three main groups (G1, G2, and G3) previously observed were also differentiated due to their proximate composition, and this, in turn, was related to flesh color in storage roots. While the
Table 1 Mean red, green and blue pixel values in the evaluated genotypes estimated from the RGB image analysis

\begin{tabular}{llll}
\hline Genotype & Red (R) & Green (G) & Blue (B) \\
\hline White-cream fleshed genotypes: & & \\
0113-671.VAL & $191.6 \pm 17.7 \mathrm{abcd}$ & $183.6 \pm 16.1 \mathrm{ab}$ & $155.6 \pm 15.1 \mathrm{a}$ \\
0113-662.VAL & $171.7 \pm 23.5 \mathrm{~d}$ & $163 \pm 21.3 \mathrm{bcde}$ & $129 \pm 19.5 \mathrm{bcd}$ \\
0113-657VAL & $206.6 \pm 17.9 \mathrm{ab}$ & $195.9 \pm 18.8 \mathrm{a}$ & $155.2 \pm 22.3 \mathrm{a}$ \\
0113-660.VAL & $195.2 \pm 18.6$ & $182.7 \pm 16 \mathrm{abc}$ & $131.2 \pm 15.6 \mathrm{abc}$ \\
0113-669.VAL & $187.8 \pm 21.4 \mathrm{bcd}$ & $174.5 \pm 20.5 \mathrm{abcd}$ & $138.4 \pm 21.1 \mathrm{abc}$ \\
0113-670VAL & $192.7 \pm 24.2 \mathrm{abcd}$ & $180.9 \pm 23.4 \mathrm{abc}$ & $132.9 \pm 24.7 \mathrm{abc}$ \\
0113-668.VAL & $193.5 \pm 21.1 \mathrm{abcd}$ & $184 \pm 25.7 \mathrm{ab}$ & $151.5 \pm 29.4 \mathrm{ab}$ \\
0113-664.VAL & $199.7 \pm 26.5 \mathrm{abc}$ & $187.8 \pm 27.2 \mathrm{ab}$ & $135.6 \pm 28.6 \mathrm{abc}$ \\
Criolla & $181.8 \pm 21.8 \mathrm{~cd}$ & $169.4 \pm 22.6 \mathrm{bcd}$ & $121.2 \pm 21.7 \mathrm{cde}$ \\
Yellow-orange fleshed genotypes: & & \\
0113-634VAL & $213.1 \pm 33.6 \mathrm{a}$ & $140.7 \pm 20.8 \mathrm{ef}$ & $71.7 \pm 26.5 \mathrm{hi}$ \\
0113-672COR & $205.5 \pm 16.9 \mathrm{abc}$ & $121.2 \pm 21.6 \mathrm{fg}$ & $56.1 \pm 14.8 \mathrm{i}$ \\
0113-673.VAL & $194.9 \pm 21.7 \mathrm{abcd}$ & $164.8 \pm 22.2 \mathrm{bcde}$ & $104.4 \pm 23.6 \mathrm{def}$ \\
0113-658 COR & $204.7 \pm 9.6 \mathrm{abc}$ & $179.3 \pm 11.2 \mathrm{abcd}$ & $98.6 \pm 13.2 \mathrm{efg}$ \\
0113-674.VAL & $187.2 \pm 19.6 \mathrm{bcd}$ & $143.8 \pm 18.3 \mathrm{ef}$ & $76.8 \pm 11.2 \mathrm{ghi}$ \\
0113-665VAL & $194.9 \pm 13.7 \mathrm{abcd}$ & $157.9 \pm 14.2 \mathrm{cde}$ & $82.9 \pm 19 \mathrm{fgh}$ \\
0113-663VAL & $192.5 \pm 30.5 \mathrm{abcd}$ & $154.7 \pm 30.4 \mathrm{de}$ & $82.9 \pm 29 \mathrm{fgh}$ \\
0113-666.VAL & $200 \pm 26.5 \mathrm{abc}$ & $163.9 \pm 30.5 \mathrm{bcde}$ & $82.8 \pm 27 \mathrm{fgh}$ \\
0113-659VAL & $199.7 \pm 24.7 \mathrm{abc}$ & $158.5 \pm 25.9 \mathrm{cde}$ & $81.4 \pm 24.8 f g h i$ \\
Purple flesh genotypes: & & \\
0113-656COR & $115.3 \pm 29.5 \mathrm{f}$ & $49.5 \pm 35.5 \mathrm{~h}$ & $73.7 \pm 35 \mathrm{ghi}$ \\
Criolla.V & $141.5 \pm 19 \mathrm{e}$ & $97.8 \pm 19.5 \mathrm{~g}$ & $92.2 \pm 18.3 \mathrm{fgh}$ \\
\hline
\end{tabular}

Different letters show significant differences determined by Tukey's test $(p<0.01)$. Red, Green, and Blue correspond to pixel values from the RGB image analysis

white-cream fleshed genotypes (G1) showed higher dry matter content compared to the yellow-orange fleshed genotypes (G2), those belonging to the $\mathrm{G} 2$ group exhibited higher AC and TPC compared to G1 (Table 2). The major level of $\mathrm{CF}$ was found in the genotypes from the G2 group compared to G1; however, an inverse relation was found in TSS, where the G1 genotypes showed higher values compared to the G2 group, except for genotype 0113-666.VAL. The purple genotypes (G3) were recognized by a profile similar to the one observed in the G1 genotypes in DMC, AC, and TPC; moreover, their level of CF and TSS was higher compared to the genotypes from the G1 and G2 groups. Consistently, Pearson's correlation between color parameters and the proximate composition showed a positive correlation between the $\mathrm{R}$ pixel value and $\mathrm{AC}$, and negative with TSS; further, the G pixel value was negatively correlated with CF; meanwhile, the B pixel value showed a positive correlation with $\mathrm{DMC}$ and a negative correlation with TPC, AC, and CF (Table 3). 


\section{Effect of days to harvest}

Twenty sweetpotato genotypes were harvested in three different periods (90, 120 and 150 DAP), where the combined mean comparison showed that late harvest (150 DAP) promotes a significantly higher accumulation of DMC and TSS, while an early harvest (90 DAP) was associated with higher accumulation of TPC and CF. Similarly, at 120 DAP, a higher accumulation of AC was observed (Fig. 2a).

The varietal analysis showed that harvest time influenced the proximal composition of the genotypes differentially, except for two genotypes, which did not exhibit any difference between harvest periods (0113665VAL and 0113-659VAL). The rest of the genotypes showed differences in specific proximal features, and only six genotypes exhibited significant differences in DMC among harvest periods (Fig. 2b, Table 4). Among these, three yellow and orange-fleshed genotypes (0113-666VAL, 0113-672COR, and 0113-634VAL) showed an increase in DMC until 120 DAP; then, a significant decrease was observed after this point. Purplefleshed genotypes did not show significant differences among harvest periods. However, the white-fleshed genotypes 0113-662VAL, 0113-664VAL, and Criolla, exhibited a constant increase throughout the evaluated period. Six genotypes showed significant differences in AC comparing the harvest periods, and most of them belonged to the white-cream flesh genotypes except for 0113-663VAL, a yellow-fleshed genotype. After 120 DAP, genotypes 0113-660VAL, 0113-664VAL, 0113-663VAL, and 0113-670VAL showed a significant decrease, while genotypes 0113-669VAL and Criolla exhibited a decrease immediately after 90 DAP.

Genotypes 0113-671VAL, 0113-657VAL, 0113668VAL, 0113-664VAL, and Criolla, all with a whitecream flesh, showed a significant reduction in TPC from 90 to 150 DAP. A similar response was observed for CF in genotypes 0133-674VAL, 0113-669VAL, and 0113-663VAL, which showed a constant decrease after 90 DAP, while genotype 0113-657VAL showed an increase up to 120 DAP, followed by a decrease at 150 DAP. A constant increase throughout the evaluated period was recorded for TSS in 10 genotypes, most of them displaying yellow and purple flesh.

\section{Effect of environmental conditions}

The environmental conditions influenced the proximate composition of sweetpotato genotypes. The conditions in Corozal promoted major accumulation of DMC compared to the rest of the locations, while Cerete and Carmen de Bolivar (Carmen B) positively influenced AC and TPC. TSS were accumulated in higher proportion in genotypes cultivated in Carmen B, Corozal, and Riohacha. The conditions in Codazzi were unfavorable for the accumulation of all the evaluated compounds (Fig. 3a). An analysis of average temperature and accumulated rainfall was done during 30 days before harvest in three locations to understand how temperature and rainfall influenced the proximal composition in sweetpotato storage roots (Fig. 3b). Accumulated rainfall above $70 \mathrm{~mm}$ during the month previous to harvest affected the DMC negatively in genotypes from the G1 (white-cream flesh) and G2 (yellow-orange flesh) groups; this observation was confirmed by a negative correlation found between rainfall and DMC (Table 5). In Carmen B and Cereté (2015A and $2015 \mathrm{~B}$ periods), the low mean temperature and rainfall influenced mainly the accumulation of $\mathrm{AC}$, TPC, and $\mathrm{CF}$ in all genotype groups. Consistently, positive correlations between accumulated rainfall and TPC, and AC and $\mathrm{CF}$ were found. A significant reduction of $\mathrm{CF}$ accumulation was observed as harvesting time increased. Otherwise, with rainfall, a reduction in TSS was found in the G1 and G3 groups. Nonetheless, a negative correlation of accumulated rainfall and TSS was consistently found, contrary to the response to temperature. In general, regardless of harvest time, there was a strong effect from environmental conditions affecting the proximate composition in the evaluated genotypes. More intense rain events 30 days before harvest affected DMC in storage roots, while $\mathrm{AC}$, TPC, and CF were more efficiently accumulated, or their proportion increased. Further, high temperatures increased TSS accumulation and reduced $\mathrm{AC}, \mathrm{TPC}$, and $\mathrm{CF}$ accumulation.

\section{Effect of the genotype by environment interaction}

The combined analysis, according to the AMMI model, showed highly significant differences among environments $(E)$, genotypes $(G)$, and their interaction $(\mathrm{GxE})$. The combined variance analysis per harvest period $(90$, 120 , and 150 DAP) was done to understand the effect of

\footnotetext{
(See figure on next page.)

Fig. 1 Diversity of root flesh color and selected chemical composition among sweetpotato genotypes. a Circular cladogram obtained from R, $\mathrm{G}$, and $\mathrm{B}$ pixel values obtained from digital images of root flesh. $\mathbf{b}$ The hierarchical clustering heatmap obtained from sweetpotato genotypes according to their proximate composition. Note: Multivariate sample similarities are displayed as a heatmap in which rows represent genotypes, and columns include compositional and color features. The heatmap encodes individual measurements for each sample (autoscaled) and measured according to the color bar at the top right of the figure. AC ash content, CF crude fiber, TPC total protein content, DMC dry matter content, TSS: total soluble solids; Red, Green, and Blue are the pixel values obtained from the image analysis
} 
a

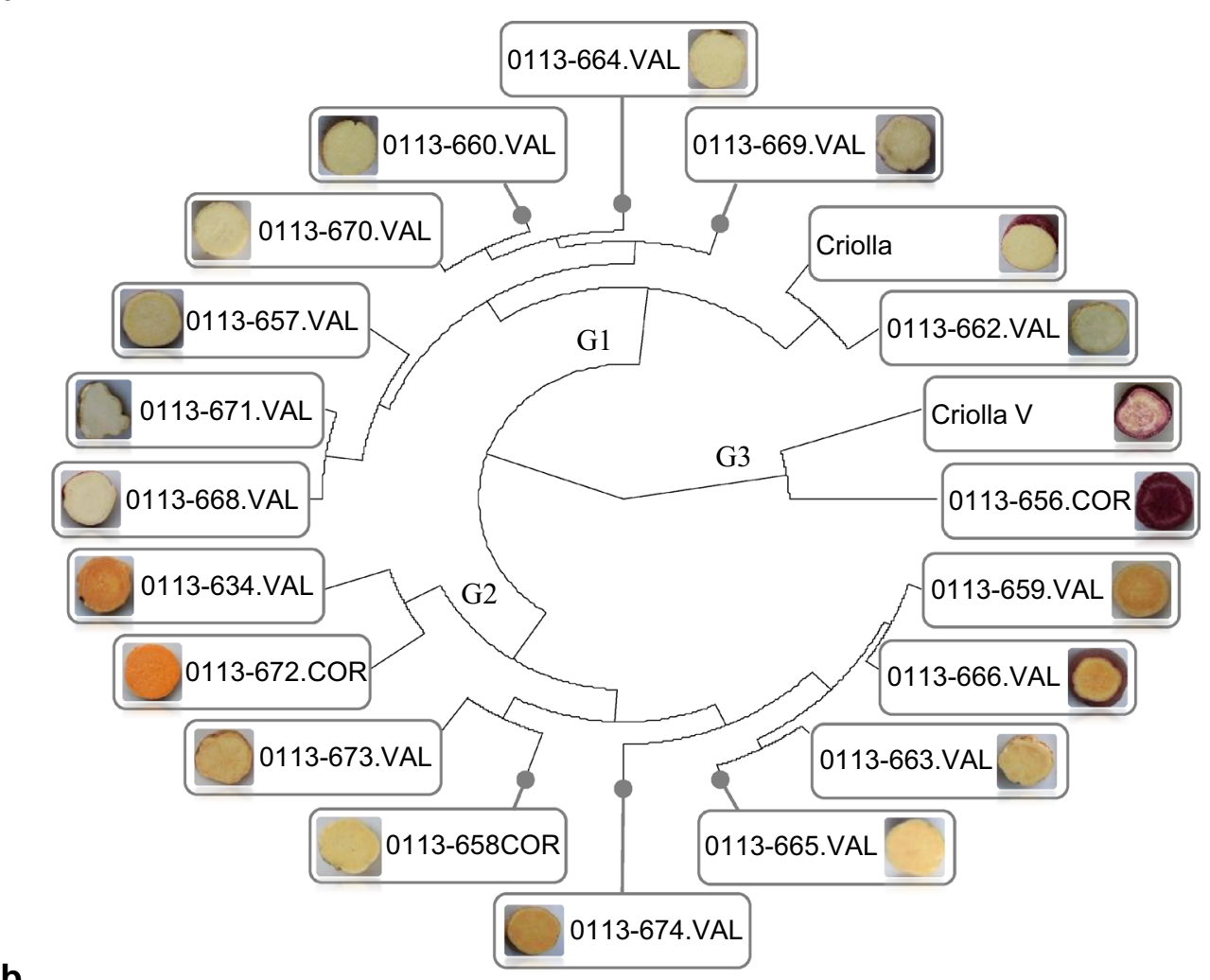

b

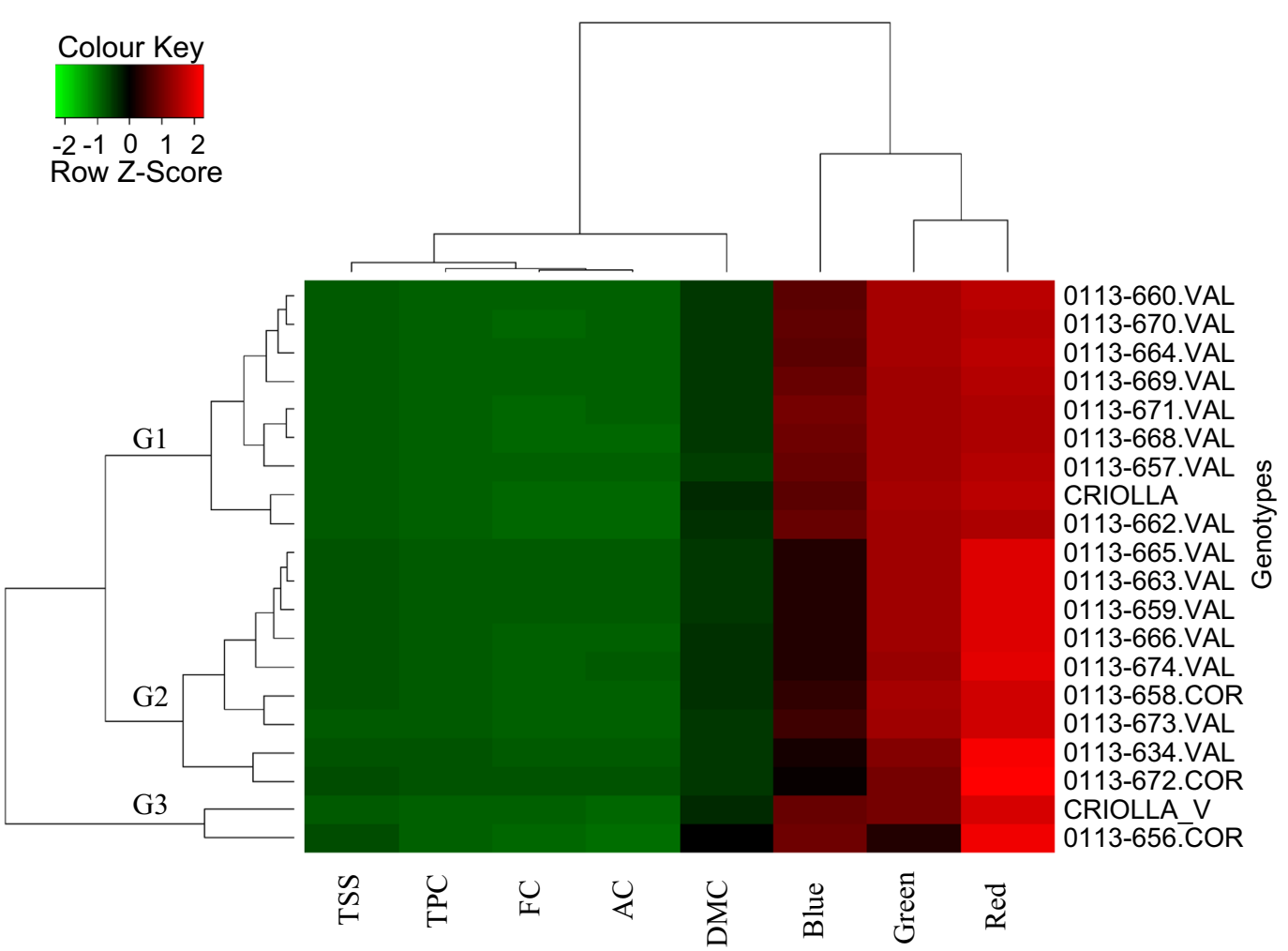


Table 2 Mean values of proximate compounds in twenty sweetpotato genotypes

\begin{tabular}{|c|c|c|c|c|c|}
\hline Genotype & DMC (\%) & $A C^{*}$ & TPC* & $\mathrm{CF}^{*}$ & TSS ( ${ }^{\circ}$ Brix) \\
\hline \multicolumn{6}{|l|}{ Cluster G1: } \\
\hline 0113-660.VAL & $35.5 \pm 4.9 \mathrm{abc}$ & $4.1 \pm 1.1 \mathrm{bcde}$ & $5.9 \pm 2.1 \mathrm{abc}$ & $3.7 \pm 1.5 \mathrm{cdef}$ & $10.2 \pm 2.7 b c$ \\
\hline 0113-670.VAL & $32.4 \pm 4.5 \mathrm{cdef}$ & $4.2 \pm 1.4 \mathrm{bcde}$ & $6.2 \pm 2.2 \mathrm{abc}$ & $3.1 \pm 0.7 f$ & $11.2 \pm 2.4 b c$ \\
\hline 0113-664.VAL & $33.8 \pm 6 b c$ & $4.1 \pm 1.4 \mathrm{bcde}$ & $6.1 \pm 2.3 \mathrm{abc}$ & $3.7 \pm 1.2 \mathrm{cdef}$ & $10.7 \pm 1.8 \mathrm{bc}$ \\
\hline 0113-669.VAL & $32 \pm 2.4 \mathrm{cdefg}$ & $4.4 \pm 1.7 \mathrm{abcde}$ & $5.6 \pm 2 a b c$ & $4 \pm 1 \mathrm{bcdef}$ & $10.6 \pm 2.6 b c$ \\
\hline 0113-671.VAL & $33.1 \pm 6.7 \mathrm{bcde}$ & $4.4 \pm 1.3 \mathrm{abcde}$ & $6.4 \pm 2.9 \mathrm{abc}$ & $3.5 \pm 1.1 \mathrm{def}$ & $9.5 \pm 3.2 \mathrm{c}$ \\
\hline 0113-668.VAL & $33.4 \pm 4.4 \mathrm{bcd}$ & $3.7 \pm 1.2 \mathrm{de}$ & $5.8 \pm 2.3 \mathrm{abc}$ & $3.9 \pm 1.4 \mathrm{bcdef}$ & $10.7 \pm 2.3 b c$ \\
\hline 0113-657.VAL & $31.7 \pm 5.6 \mathrm{cdefgh}$ & $3.8 \pm 1.1 \mathrm{cde}$ & $5.4 \pm 2.4 b c$ & $4 \pm 1.4$ abcdef & $9.8 \pm 3.6 c$ \\
\hline Criolla & $39.3 \pm 5.8 \mathrm{a}$ & $3.4 \pm 0.5 \mathrm{e}$ & $5.3 \pm 1.9 b c$ & $4.7 \pm 1.7 \mathrm{abc}$ & $10.8 \pm 2.6 b c$ \\
\hline 0113-662.VAL & $33.7 \pm 4.1 \mathrm{bc}$ & $3.8 \pm 0.6 \mathrm{cde}$ & $4.5 \pm 1.6 c$ & $4.1 \pm 1.5 \mathrm{abcdef}$ & $10.4 \pm 2.9 b c$ \\
\hline Group mean & $33.8 \pm 5.8 a$ & $4.0 \pm 1.2 b$ & $5.9 \pm 2.4 b$ & $3.8 \pm 1.3 b$ & $10.4 \pm 2.8 \mathrm{~b}$ \\
\hline \multicolumn{6}{|l|}{ Cluster G2 } \\
\hline 0113-665.VAL & $27.2 \pm 3.2 \mathrm{hi}$ & $4.9 \pm 1.9 \mathrm{abc}$ & $7.2 \pm 3.1 \mathrm{ab}$ & $4.4 \pm 1$ abcde & $9.2 \pm 2.9 c$ \\
\hline 0113-663.VAL & $27.8 \pm 3.9 \mathrm{ghi}$ & $4.4 \pm 1.2 \mathrm{abcde}$ & $7 \pm 3.2 \mathrm{ab}$ & $4.4 \pm 1.4 \mathrm{abcde}$ & $9.5 \pm 2.4 c$ \\
\hline 0113-659.VAL & $26.3 \pm 3.5 i$ & $4.7 \pm 1.5 \mathrm{abcd}$ & $6.6 \pm 3.1 \mathrm{abc}$ & $4.8 \pm 1.4 \mathrm{abc}$ & $9 \pm 2.9 c$ \\
\hline 0113-666.VAL & $32.8 \pm 4.3 \mathrm{cde}$ & $4.4 \pm 1.7 \mathrm{abcde}$ & $6.9 \pm 3.6 a b$ & $3.3 \pm 0.9 \mathrm{ef}$ & $12.4 \pm 3.2 \mathrm{ab}$ \\
\hline 0113-674.VAL & $28.5 \pm 3.7$ efghi & $4.7 \pm 1.3 \mathrm{abcd}$ & $7.5 \pm 3.5 \mathrm{ab}$ & $3.9 \pm 0.7 \mathrm{bcdef}$ & $9.5 \pm 1.8 c$ \\
\hline 0113-658.COR & $35 \pm 6 a b c$ & $4.7 \pm 2.6 \mathrm{abcd}$ & $6.2 \pm 3.2 \mathrm{abc}$ & $3.2 \pm 0.7 f$ & $10 . \pm 2.5 b c$ \\
\hline 0113-673.VAL & $28 \pm 6.5 f g h i$ & $4.8 \pm 1.4 \mathrm{abcd}$ & $6 \pm 2.4 a b c$ & $4.2 \pm 1.4$ abcdef & $9 \pm 2.1 c$ \\
\hline 0113-634.VAL & $26.7 \pm 4.5 i$ & $5.1 \pm 1.3 \mathrm{ab}$ & $7.8 \pm 3 a$ & $4.5 \pm 1.3 \mathrm{abcde}$ & $10.4 \pm 2.4 b c$ \\
\hline 0113-672.COR & $21.5 \pm 4.7 j$ & $5.5 \pm 1.5 \mathrm{a}$ & $7 \pm 2.7 a b$ & $5.1 \pm 1.4 a$ & $9.3 \pm 1.8 c$ \\
\hline Group mean & $26.9 \pm 5.6 b$ & $4.9 \pm 1.5 \mathrm{a}$ & $6.9 \pm 3.0 \mathrm{a}$ & $4.4 \pm 1.3 \mathrm{a}$ & $9.6 \pm 2.5 b$ \\
\hline \multicolumn{6}{|l|}{ Cluster G3: } \\
\hline 0113-656.COR & $37.5 \pm 6.4 \mathrm{ab}$ & $3.7 \pm 1.1 \mathrm{de}$ & $6.3 \pm 2.5 \mathrm{abc}$ & $4.5 \pm 1.7 \mathrm{abcd}$ & $14.2 \pm 3.9 \mathrm{a}$ \\
\hline Criolla.V & $29.2 \pm 4.4$ defghi & $3.9 \pm 0.5 \mathrm{cde}$ & $5.3 \pm 1.9 b c$ & $4.8 \pm 1.9 a b$ & $10.4 \pm 2 b c$ \\
\hline Group mean & $35.0 \pm 7.0 \mathrm{a}$ & $3.8 \pm 1.0 \mathrm{~b}$ & $6.0 \pm 2.4 b$ & $4.6 \pm 1.7 a$ & $13.3 \pm 3.9 a$ \\
\hline
\end{tabular}

$D M C$ dry matter content, $A C$ ash content, $C F$ crude fiber, TPC total protein content, TSS total soluble solids

Different letters show significant differences among genotypes or groups determined by Tukey's test $(p<0.01)$; ${ }^{*} \mathrm{~g} / 100 \mathrm{~g}$ of dry weight

Table 3 Pearson's correlation between color parameters and selected quality features in sweetpotato

\begin{tabular}{lcccccc}
\hline Variable & DMC & TPC & AC & CF & TSS & Red \\
\hline TP & $-0.55^{*}$ & & & & \\
AC & $-0.8^{* *}$ & $0.73^{*}$ & & & \\
CF & $-0.46^{*}$ & 0.07 & 0.15 & & & \\
TSS & $0.63^{*}$ & -0.14 & $-0.49^{*}$ & -0.21 & & \\
Red & -0.36 & 0.33 & $0.51^{*}$ & -0.29 & $-0.59^{*}$ & $0.76^{* *}$ \\
Green & 0.16 & -0.2 & -0.05 & $-0.59^{*}$ & -0.44 & 0.13 \\
Blue & $0.55^{*}$ & $-0.65^{*}$ & $-0.59^{*}$ & $-0.53^{*}$ & -0.03 & $0.68^{* *}$ \\
\hline
\end{tabular}

$D M C$ dry matter content, $A C$ ash content, CF crude fiber, TPC total protein content, TSS total soluble solids

Red, Green, and Blue correspond to pixel values from the RGB image analysis. ${ }^{* * *}(p<0.0001),{ }^{* *}(p<0.001),{ }^{*}(p<0.01)$

(See figure on next page.)

Fig. 2 Comparison of the effect of harvest time on the proximate content in sweetpotato. a Mean comparison between 90, 120, and 150 DAP in proximate composition. $\mathbf{b}$ The response of the evaluated sweetpotato genotypes to harvest time at 90, 120, and 150 DAP. AC ash content, CF crude fiber, TPC total protein content, DMC dry matter content, TSS total soluble solids. Different letters show significant differences established by Tukey's test $(p<0.01)$. ns no significant differences among harvest periods, and only genotypes that report significant differences were graphed. *measured in $\mathrm{g} / 100 \mathrm{~g}$ of dry weight, ${ }^{* *}$ measured in ${ }^{\circ}$ Brix 
a

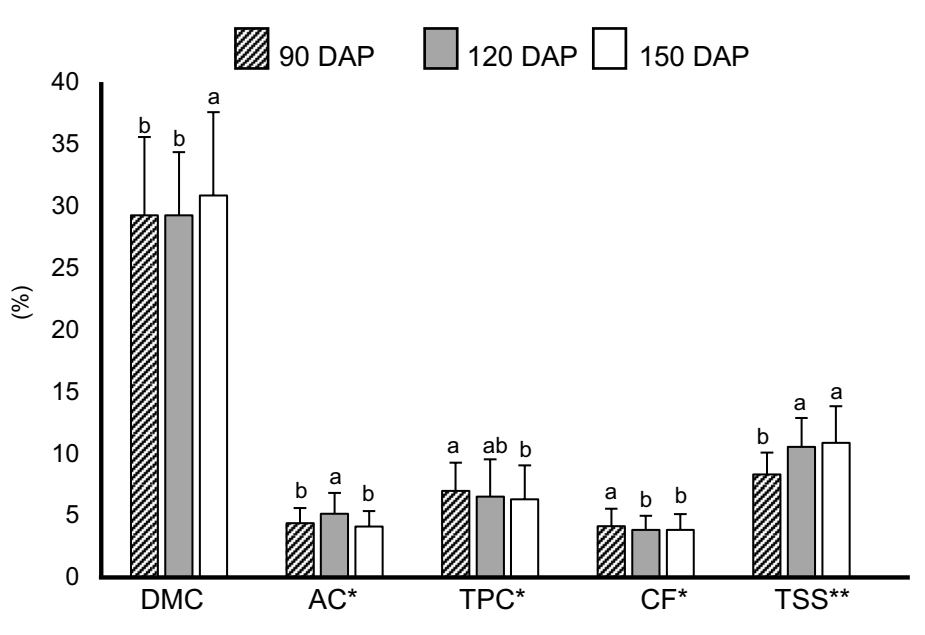

b

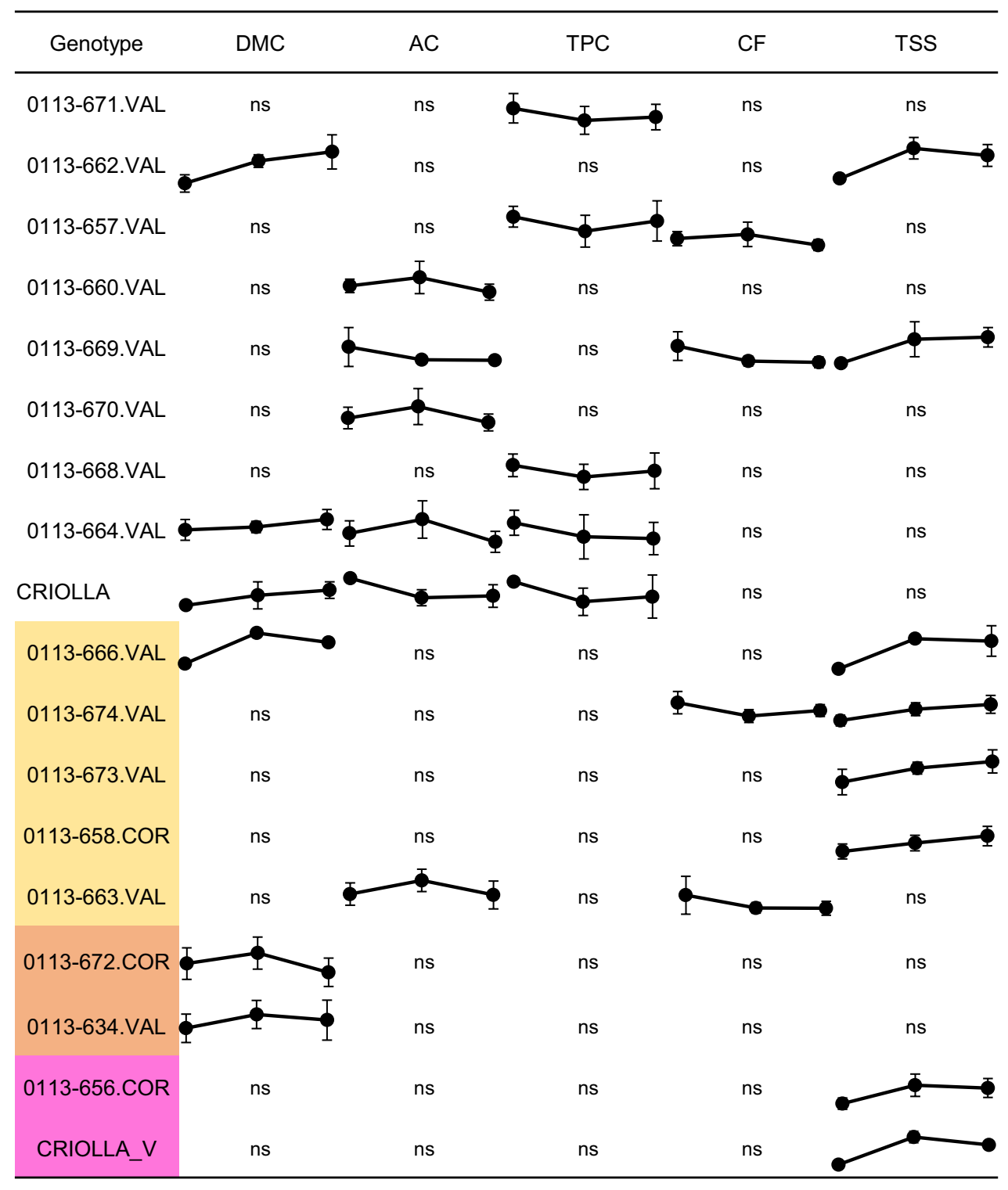


Table 4 Mean values of the proximate compounds grouped in clusters at different harvesting periods

\begin{tabular}{|c|c|c|c|c|c|}
\hline Harvest time & DMC (\%) & $A C^{*}$ & TPC* & $\mathrm{CF}^{*}$ & TSS ( ${ }^{\circ}$ Brix) \\
\hline \multicolumn{6}{|l|}{ Cluster G1 } \\
\hline 90 & $31.2 \pm 5.3 \mathrm{Ab}$ & $4.2 \pm 1.3 \mathrm{a}$ & $7.1 \pm 2.1 \mathrm{a}$ & $3.7 \pm 1.1 \mathrm{~B}$ & $8.5 \pm 1.7 c$ \\
\hline 120 & $33.8 \pm 4.7 \mathrm{Aa}$ & $4.3 \pm 1.4 \mathrm{Ba}$ & $5.2 \pm 2.4 \mathrm{Bb}$ & $3.9 \pm 1.6$ & $10.1 \pm 3.2 \mathrm{Bb}$ \\
\hline 150 & $35.2 \pm 6.3 \mathrm{Aa}$ & $3.6 \pm 0.8 \mathrm{Bb}$ & $5.7 \pm 2.3 \mathrm{Bb}$ & $3.6 \pm 1.3 \mathrm{~B}$ & $11 \pm 2.4 \mathrm{Ba}$ \\
\hline \multicolumn{6}{|l|}{ Cluster G2 } \\
\hline 90 & $25.9 \pm 6.5 B$ & $4.6 \pm 1.2 b$ & $7 \pm 2.5$ & $4.7 \pm 1.7 \mathrm{~A}$ & $8 \pm 1.8 b$ \\
\hline 120 & $26.8 \pm 4.5 B$ & $5.3 \pm 1.7 \mathrm{Aa}$ & $7.1 \pm 3.2 \mathrm{~A}$ & $4.4 \pm 1.3$ & $9.7 \pm 1.8 \mathrm{Ba}$ \\
\hline 150 & $27.4 \pm 6.1 \mathrm{~B}$ & $4.6 \pm 1.5 \mathrm{Ab}$ & $6.8 \pm 3.1 \mathrm{~A}$ & $4.3 \pm 1.2 \mathrm{~A}$ & $10 \pm 3 \mathrm{Ca}$ \\
\hline \multicolumn{6}{|l|}{ Cluster G3 } \\
\hline 90 & $29.8 \pm 6.4 \mathrm{ABb}$ & $3.8 \pm 0.8$ & $6 \pm 2.2$ & $4.2 \pm 1.1 \mathrm{AB}$ & $8.5 \pm 1.9 b$ \\
\hline 120 & $33.9 \pm 6.2 \mathrm{Aab}$ & $4.3 \pm 1.5 \mathrm{AB}$ & $6.1 \pm 2.5 \mathrm{AB}$ & $5 \pm 1.4$ & $14.7 \pm 3.7 \mathrm{Aa}$ \\
\hline 150 & $37.3 \pm 6.4 \mathrm{Aa}$ & $3.6 \pm 0.7 \mathrm{~B}$ & $6 \pm 2.5 \mathrm{AB}$ & $4.6 \pm 2 \mathrm{~A}$ & $14 \pm 3.4 \mathrm{Aa}$ \\
\hline
\end{tabular}

$D M C$ dry matter content, $A C$ ash content, CF crude fiber, TPC total protein content, TSS total soluble solids

Different capital letters indicate significant differences among clusters at the same harvest time, and lower-case letters indicate significant differences among harvest time in the respective clusters determined by the LSD test $(p<0.01) ;{ }^{*} \mathrm{~g} / 100 \mathrm{~g}$ of dry weight

environments, genotypes, and their interaction ( $G \times E)$ on the proximate composition in storage roots of sweetpotato. The results showed a significant contribution of the environment and the genotype to the total variance. The effect of the environment was higher than the genotype for all root quality parameters at 90, 120, and 150 DAP (Additional file 1: Table S1). The GxE interaction was significant for DMC, AC, and CF at 90 and 120 DAP, and for TPC, only a significant contribution was observed at $150 \mathrm{DAP}$. The variance of the error remained within the permitted margins for the measurement of the variables under study.

The selected genotypes were tested through a multilocal evaluation and were harvested at 120 to 150 DAP, according to the maturity period. The combined analysis showed that all sources of variation were significant according to the additive main effects and multiplicative interaction (AMMI) model assuming location and season as the aggregate single environmental factor (Table 6). A higher contribution of the genotype to the total variance for DMC compared to the environment was found. The environment showed a high and significant contribution for AC, TPC, CF, and TSS compared to the genotype and the GxE interaction. Furthermore, this interaction was significant only for CF and TSS. The mean comparison confirmed, as discussed above, that white- or cream-fleshed genotypes showed significantly higher DMC compared to orange-fleshed, as observed in genotypes 0113-672.COR and 0113-634.VAL (Table 7), which are yellow-orange fleshed genotypes with low DMC. In contrast, these genotypes showed higher $\mathrm{AC}$ values compared to white and purple genotypes, and the TPC content was comparable to purple-fleshed genotypes (0113-656.COR), which also showed the highest TSS content. Environmental conditions influenced the evaluated quality traits differently; in general, environmental conditions that influenced positively DMC generated lower AC and TPC values (Table 7).

The environments of Carmen B and Cerete induced DM accumulation in a range value from 31.2 to $36 \%$, showing a good level of AC and TPC. The conditions in Corozal promoted the accumulation of TSS. The highest overall average of DMC was found in the genotype Criolla.V with $41.5 \%$, which presented phenotypic stability throughout the environments. This genotype, together with 0113-660.VAL was associated with the Corozal_2015B environment (Fig. 4a). Despite their high content of DMC, genotypes 0113-656.COR, Criolla, and 0113-664.VAL showed instability. The environments of Corozal_2016B and Codazzi_2015 were the

(See figure on next page.)

Fig. 3 Effect of environmental conditions and harvest time on proximate composition in the sweetpotato genotypes assessed. a Mean comparison in proximate composition between five locations. b The response of the evaluated sweetpotato genotypes to harvest time at 90, 120, and 150 DAP in selected environments/seasons. Note: maximum values are represented by an intense blue or red color, and minimum values are represented by light red or blue, or intense green color. AC ash content, CF crude fiber, TPC total protein content, DMC dry matter content, TSS total soluble solids, DAP days after planting, MT mean temperature, AR accumulated rainfall. ND no data available. Different letters show significant differences, according to Tukey's test $(p<0.01)$. *measured in $\mathrm{g} / 100 \mathrm{~g}$ of dry weight, ${ }^{* *}$ measured in ${ }^{\circ} B r i x$ 
a

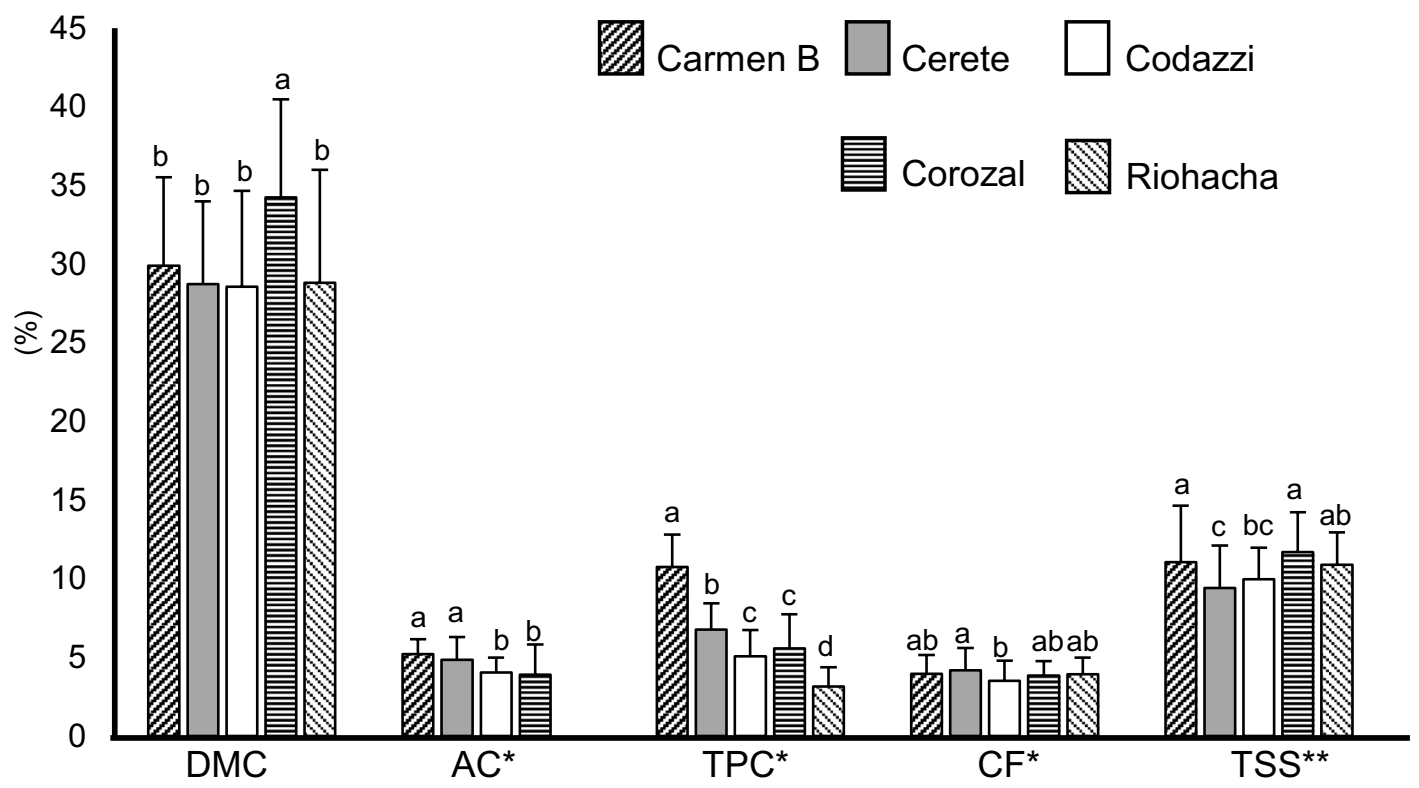

b

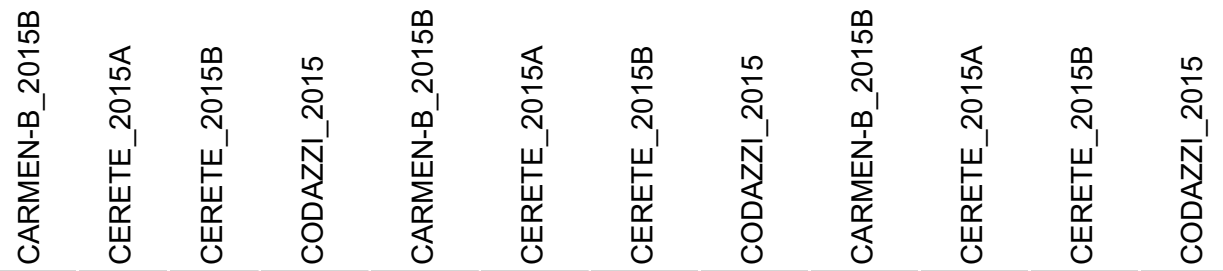

\begin{tabular}{|l|c|c|c|c|c|c|c|c|c|c|c|c|}
\hline DAP & 90 & 90 & 90 & 90 & 120 & 120 & 120 & 120 & 150 & 150 & 150 & 150 \\
\hline MT( $\left.{ }^{\circ} \mathrm{C}\right)$ & 28 & 28.9 & 27.8 & 30.2 & 28.5 & 28.8 & 28.8 & 32.1 & 28 & 28.4 & 28.9 & 32.6 \\
\hline AR(mm) & 64.7 & 79.3 & 206 & 10.6 & 54.5 & 78 & 31.9 & 2.1 & 0 & 207.2 & 14.3 & 20.2 \\
\hline DMC-G1 & 28.4 & 33.08 & 30.11 & 28.19 & 31.40 & 31.24 & 31.09 & 30.29 & 37.50 & 29.45 & 32.91 & 33.95 \\
\hline DMC-G2 & 25.25 & 21.32 & 21.42 & 25.34 & 26.14 & 25.31 & 25.31 & 25.41 & 28.77 & 23.31 & 26.21 & 27.42 \\
\hline DMC-G3 & ND & ND & 30.46 & 27.59 & 46.63 & ND & 38.09 & 29.94 & ND & 33.14 & 38.68 & 30.67 \\
\hline AC-G1 & 5.29 & 4.38 & 4.85 & 3.58 & 4.60 & 6.89 & 3.99 & 3.66 & 4.39 & 3.93 & 3.81 & 3.94 \\
\hline AC-G2 & 5.68 & 5.42 & 6.13 & 4.19 & 5.64 & 8.36 & 5.26 & 4.31 & 5.83 & 4.89 & 4.91 & 4.83 \\
\hline AC-G3 & ND & ND & 4.89 & 3.61 & 5.55 & ND & 3.38 & 3.88 & ND & 4.46 & 3.41 & 3.88 \\
\hline TPC-G1 & 9.54 & 6.70 & 7.35 & 4.84 & 9.75 & 3.56 & 6.19 & 5.05 & 10.05 & 5.51 & 6.63 & 4.72 \\
\hline TPC-G2 & 10.70 & 8.03 & 8.96 & 4.99 & 11.78 & 4.45 & 7.93 & 5.90 & 12.61 & 7.46 & 7.73 & 4.96 \\
\hline TPC-G3 & ND & ND & 8.72 & 4.95 & 11.97 & ND & 6.29 & 5.70 & ND & 7.37 & 7.31 & 4.79 \\
CF-G1 & 3.90 & 3.56 & 4.85 & 2.99 & 3.28 & 3.15 & 3.85 & 3.19 & 2.74 & 3.56 & 3.16 & 3.10 \\
\hline CF-G2 & 5.73 & 4.41 & 7.49 & 3.54 & 4.29 & 3.64 & 4.73 & 3.78 & 4.50 & 4.46 & 4.23 & 3.62 \\
\hline CF-G3 & ND & ND & 6.09 & 3.65 & 5.17 & ND & 6.93 & 4.33 & ND & 3.70 & 2.80 & 5.00 \\
\hline TSS-G1 & 10.40 & ND & 7.58 & 8.48 & 10.81 & ND & 9.67 & 11.97 & 14.11 & 9.17 & 10.10 & 10.44 \\
\hline TSS-G2 & 9.10 & ND & 7.18 & 8.17 & 9.76 & ND & 8.38 & 11.83 & 10.07 & 7.69 & 9.69 & 10.23 \\
\hline TSS-G3 & ND & ND & 10.93 & 7.29 & 21.40 & ND & 16.63 & 12.43 & ND & 17.17 & 17.50 & 10.86
\end{tabular}


Table 5 Pearson's correlation between harvest time, environmental conditions and selected quality features in sweetpotato genotypes

\begin{tabular}{|c|c|c|c|c|c|c|c|c|}
\hline Traits & $\mathbf{N}$ & DAP & DMC & TPC & $A C$ & $\mathrm{CF}$ & TSS & Temperature \\
\hline \multicolumn{9}{|c|}{ Combined analysis } \\
\hline DAP & 120 & 1 & & & & & & \\
\hline DMC & 119 & $0.22^{*}$ & & & & & & \\
\hline TPC & 120 & -0.14 & $-0.34^{* *}$ & & & & & \\
\hline$A C$ & 120 & -0.1 & $-0.45^{* * *}$ & $0.34^{* *}$ & & & & \\
\hline CF & 120 & $-0.28^{*}$ & $-0.36^{* *}$ & $0.52^{* * *}$ & $0.39^{* * *}$ & & & \\
\hline TSS & 97 & $0.31^{*}$ & $0.34^{* *}$ & -0.08 & $-0.3^{*}$ & -0.2 & & \\
\hline Temperature & 120 & $0.34^{* *}$ & 0.15 & $-0.55^{* * *}$ & $-0.35^{* *}$ & $-0.42^{* * *}$ & $0.44^{* * *}$ & \\
\hline Rainfall & 120 & $-0.27^{*}$ & $-0.21^{*}$ & $0.42^{* * *}$ & $0.38^{* * *}$ & $0.53^{* * *}$ & $-0.4^{* * *}$ & $-0.65^{* * *}$ \\
\hline
\end{tabular}

$D A P$ days after planting, DMC dry matter content, $A C$ ash content, $C F$ crude fiber, $T P C$ total protein content, $T S S$ total soluble solids

$* * *(p<0.0001), * *(p<0.001), *(p<0.01)$

Table 6 Combined analysis and additive main effects and multiplicative interaction (AMMI) analysis of variance for selected quality traits in nine sweetpotato genotypes across nine environments

\begin{tabular}{|c|c|c|c|c|c|c|}
\hline Effect & Df. & DMC & $A C$ & TPC & CF & TSS \\
\hline Genotype & 9 & $694.61^{* * *}$ & $15.42^{* * *}$ & $23.90^{* * *}$ & $5.43^{* * *}$ & $75.29^{* * *}$ \\
\hline Environ. & 8 & $414.98^{* * *}$ & $18.82^{* * *}$ & $113.57^{* * *}$ & $21.24^{* * *}$ & $117.20^{* * *}$ \\
\hline Genotype*environ. & 57 & $39.85^{* * *}$ & $2.02^{* * *}$ & $3.98^{* * *}$ & $3.84^{* * *}$ & $12.49^{* * *}$ \\
\hline Residuals & 161 & 6.66 & 0.34 & 1.52 & 1.24 & 2.33 \\
\hline PC1 & & $128.4^{* * *}(64.8 \%)$ & $4.82^{* * *}(53.8 \%)$ & $10.09^{* * *}(53.9 \%)$ & $6.03^{* * *}(34.3 \%)$ & $23.43^{* * *}(43.1 \%)$ \\
\hline PC2 & & $37.3^{* * *}(16.5 \%)$ & $3.10^{* * *}(30.3 \%)$ & $4.57^{* * *}(21.4 \%)$ & $6.26^{* * *}(31.2 \%)$ & $16.86^{* * *}(27.1 \%)$ \\
\hline
\end{tabular}

$d f$ degrees of freedom, AC: DMC dry matter content, ash content, CF crude fiber, TPC total protein content, Environ. environment

The values correspond to the mean square in the evaluated traits. ${ }^{* *}(p<0.0001),{ }^{* *}(p<0.001){ }^{*}(p<0.01)$

ones that contributed most to the variance of the interaction. In relation to the $\mathrm{GxE}$ interaction associated with the accumulation of $\mathrm{AC}$ (Fig. 4b), with the exception of 0113-634.VAL, the genotypes with the highest value for this parameter, were unstable. In this sense, genotypes Criolla, Criolla.V, and 0113-656.COR were stable, and the environments Corozal_2015B and Cerete_2015A contributed to the highest variance of the interaction. The variance for the GxE interaction indicated higher stability of the genotypes 0113-671.VAL and 0113-668. VAL for TPC and the interaction was significant for the four locations (Fig. 4c). Genotype 0113-672.COR showed the highest overall average $\mathrm{CF}$, but exhibited instability across environments (Fig. 4d). Nevertheless, at least three environments (Corozal, Carmen-B_2016, and Cerete_2016B) affected the variance of the interaction for CF. Genotypes, 0113-634.VAL, 0113-668.VAL and 0113-671.VAL were stable and were also associated with the environments Carmen-B_2015B, Cerete_2015B, and Tolu_2016B, respectively. Genotypes Criolla.V, Criolla, 0113-660.VAL and 0113-664.VAL were stable for TSS. Cerete_2016B and Codazzi_2015 were the environments that contributed most to this interaction (Fig. 4e).
The most significant contributor to the variance was the environment, followed by the genotype. Nonetheless, the interaction suggested that some genotypes were not stable across environments, responding differently to distinct environments. Highly contrasting locations and seasons contributed to the high variance for all the proximate compounds, confirming our previous observations described above concerning rainfall, temperature, and soil conditions.

\section{Discussion}

The diversity reported in this study was consistent with the information registered for sweetpotato, where more than 6,000 cultivars have been reported, including landraces, production lines, and improved cultivars, differentiated by the color of their skin (creamy-white, yellow, orange, brown, or purple) and their flesh (white, yellow, orange, pink, or purple), their texture (soft or rough), and their uses (direct consumption and industrial processing) $[39,55]$. This vast phenotypical diversity in sweetpotato directly influences the nutrient content. However, the visual differences can be improved and expanded by quantifying either by RGB images or colorimetry techniques 
Table 7 Mean values in proximate composition in nine selected sweetpotato genotypes and environments

\begin{tabular}{|c|c|c|c|c|c|c|c|}
\hline & Group & $\begin{array}{l}\text { Days } \\
\text { to maturity }\end{array}$ & DMC (\%) & $A C^{*}$ & TPC* & $\mathrm{CF}^{*}$ & TSS ('Brix) \\
\hline \multicolumn{8}{|l|}{ Genotype: } \\
\hline 0113-671.VAL & G1 & 120 & $33.71 \pm 3.58$ de & $4.51 \pm 1.41 b c$ & $5.46 \pm 2.79 a b$ & $3.75 \pm 1.42 b$ & $8.98 \pm 4.09 b$ \\
\hline 0113-657.VAL & G1 & 120 & $32.67 \pm 5.65 \mathrm{e}$ & $3.86 \pm 1.14 \mathrm{~cd}$ & $4.5 \pm 2.25 b$ & $4.52 \pm 1.6 \mathrm{ab}$ & $9.12 \pm 4.38 b$ \\
\hline 0113-660.VAL & G1 & 150 & $37.2 \pm 4.64 \mathrm{bcd}$ & $3.64 \pm 0.75 \mathrm{~cd}$ & $5.9 \pm 1.87 a b$ & $3.83 \pm 1.55 b$ & $10.54 \pm 3.14 b$ \\
\hline 0113-668.VAL & G1 & 120 & $34.53 \mathrm{de} \pm 4.03 \mathrm{c}$ & $3.85 \pm 1.4 \mathrm{~cd}$ & $5.14 \pm 2 b$ & $4.1 \pm 1.53 \mathrm{ab}$ & $10.48 \pm 2.29 b$ \\
\hline 0113-664.VAL & G1 & 150 & $37.03 \pm 5.84 \mathrm{bcd}$ & $3.46 \pm 0.88 \mathrm{~d}$ & $5.73 \pm 2.07 a b$ & $3.78 \pm 1.42 b$ & $10.5 \pm 1.94 b$ \\
\hline Criolla & G1 & 120 & $38.77 \pm 7.02 \mathrm{abc}$ & $3.24 \pm 0.39 d$ & $4.76 \pm 1.49 b$ & $4.72 \pm 1.92 \mathrm{ab}$ & $11.05 \pm 2.45 b$ \\
\hline Criolla & G1 & 150 & $41.5 \pm 4.35 a$ & $3.33 \pm 0.55 d$ & $5.32 \pm 2.36 a b$ & $4.67 \pm 1.68 \mathrm{ab}$ & $11.13 \pm 2.66 b$ \\
\hline 0113-672.COR & G2 & 120 & $23.6 \pm 4.32 \mathrm{~g}$ & $5.52 \pm 1.34 a$ & $6.42 \pm 2.36 a b$ & $5.24 \pm 1.54 a$ & $9.22 \pm 1.61 b$ \\
\hline 0113-634.VAL & G2 & 120 & $28.04 \pm 3.82 f$ & $5.1 \pm 1.46 a b$ & $7.2 \pm 3.07 a$ & $4.56 \pm 1.28 \mathrm{ab}$ & $10.16 \pm 1.88 b$ \\
\hline 0113-656.COR & G3 & 150 & $38.86 \pm 5.82 \mathrm{ab}$ & $3.46 \pm 0.72 d$ & $6.4 \pm 2.44 a b$ & $4.39 \pm 1.72 a b$ & $14.56 \pm 3.53 a$ \\
\hline \multicolumn{8}{|l|}{ Environment: } \\
\hline Codazzi_2015 & & & $27.8 \pm 7 e$ & $4 \pm 0,8 \mathrm{bcd}$ & $5.3 \pm 2.2 c$ & $3.3 \pm 1.3 c$ & $11.6 \pm 1.3 a b$ \\
\hline Corozal_2015B & & & $32.8 \pm 5.8 \mathrm{bcd}$ & $4.7 \pm 2.1 \mathrm{bc}$ & $4.7 \pm 2.2 \mathrm{~cd}$ & $3.9 \pm 1.2 b c$ & $11.7 \pm 2.6 a b$ \\
\hline Corozal_2016B & & & $38 \pm 9.4 a$ & $2.9 \pm 0.6 e$ & $6 \pm 1.5 b c$ & $4.7 \pm 1.7 \mathrm{ab}$ & $12.9 \pm 2.8 \mathrm{a}$ \\
\hline Carmen-B_2015B & & & $31.3+6 \mathrm{cde}$ & $4.9 \pm 0.7 b$ & $10.2 \pm 1.3 \mathrm{a}$ & $3.4 \pm 0.9 c$ & $11.7 \pm 2.1 \mathrm{ab}$ \\
\hline Carmen-B_2016B & & & $36.5+4.6 a b$ & $4 \pm 0.7 \mathrm{bcd}$ & $6.8 \pm 2.4 b$ & $4.9 \pm 1.4 a b$ & $9.7 \pm 1.7 b$ \\
\hline Cerete_2015A & & & $28.5 \pm 4.9 \mathrm{de}$ & $5.8 \pm 2 a$ & $4.9 \pm 1.4 \mathrm{~cd}$ & $3.5 \pm 0.9 c$ & $11.6 \pm 4.8 \mathrm{ab}$ \\
\hline Cerete_2015B & & & $31.4 \pm 5.4 \mathrm{cde}$ & $4.1 \pm 1.2 \mathrm{bcd}$ & $6.8 \pm 1.2 \mathrm{~b}$ & $3.5 \pm 1.1 \mathrm{c}$ & $10.2 \pm 3.3 b$ \\
\hline Cerete_2016B & & & $36 \pm 5.5 \mathrm{abc}$ & $3.8 \pm 0.8 \mathrm{~cd}$ & $3.8 \pm 1.3 d$ & $5.3 \pm 1.8 \mathrm{a}$ & $6.7 \pm 3.6 c$ \\
\hline Tolu_2016B & & & $36.9 \pm 4.8 \mathrm{ab}$ & $3.7 \pm 0.8 \mathrm{de}$ & $3.7 \pm 1.1 d$ & $5.2 \pm 1.6 \mathrm{a}$ & $11.3 \pm 2.1 \mathrm{ab}$ \\
\hline
\end{tabular}

$D M C$ dry matter content, $A C$ ash content, CF crude fiber, TPC total protein content, TSS total soluble solids

Groups correspond to previously described clusters obtained by HCA. Different letters show significant differences determined by Tukey's test ( $p<0.01$ ); ${ }^{*} \mathrm{~g} / 100 \mathrm{~g}$ of dry weight

that respond to several types of pigments such as anthocyanidins that show red or purple colors, $\beta$-carotene that is observed as yellow or orange, and flavonoids, which display a yellow color [45]. In this study, R, G, and B pixel values were measured employing an image analysis, and surprisingly, these were related to quality attributes estimated through the proximate analysis. The hierarchical analysis discriminated three groups that were differentiated by pixel values, and later, by the proximate composition, demonstrating the enormous potential of this cost-effective phenotypic characterization to determine crop diversity and recognize the potential use-value of a particular genotype. Therefore, these results consistently showed that color description by quantifying pixel values was a method that exceedingly improves color differentiation in plants [22]. R, G, and B pixel values were efficient parameters for food quality determination in sweetpotato, as previously reported in other crops such as quinoa [16], and for fruit ripening quality in mango [12], citrus [19], and plum [21]. In this study, low B pixel values were found in pigmented genotypes (yellow, orange, and purple-fleshed storage roots) that, beyond their pigments, were also related to ash and protein accumulation, especially in yellow-orange genotypes. Moreover, cream and white-fleshed genotypes showed higher DMC compared to yellow and orange-fleshed genotypes, and consistently, a positive correlation with B pixel values was found. Purple flesh genotypes showed similar DMC and higher CF and TSS values compared to white genotypes. The positive correlation of DMC with $\mathrm{B}$ pixel values was consistent with previous reports that showed how the DMC in sweetpotato declines with increasing carotenoid content [47]. However, consistent with previous reports, the orange color was notable for its high

(See figure on next page.)

Fig. 4 The additive main effects and multiplicative interaction (AMMI) model biplot for proximate compounds in nine sweetpotato genotypes an in nine environments. a Biplot for dry matter content (DMC), $\mathbf{b}$ biplot for ash content (AC), $\mathbf{c}$ biplot for total protein content (TPC), $\mathbf{d}$ biplot for crude fiber (CF), and e biplot for total soluble solids (TSS). Ci1: Codazzi_2015, Cl1: Corozal_2015B, CI2: Corozal_2016B, CB1: Carmen-B_2015B, CB2: Carmen-B_2016B, Ce1: Cerete_2015A, Ce2: Cerete_2015B, Ce3: Cerete_2016B, and T1:Tolu_2016B 

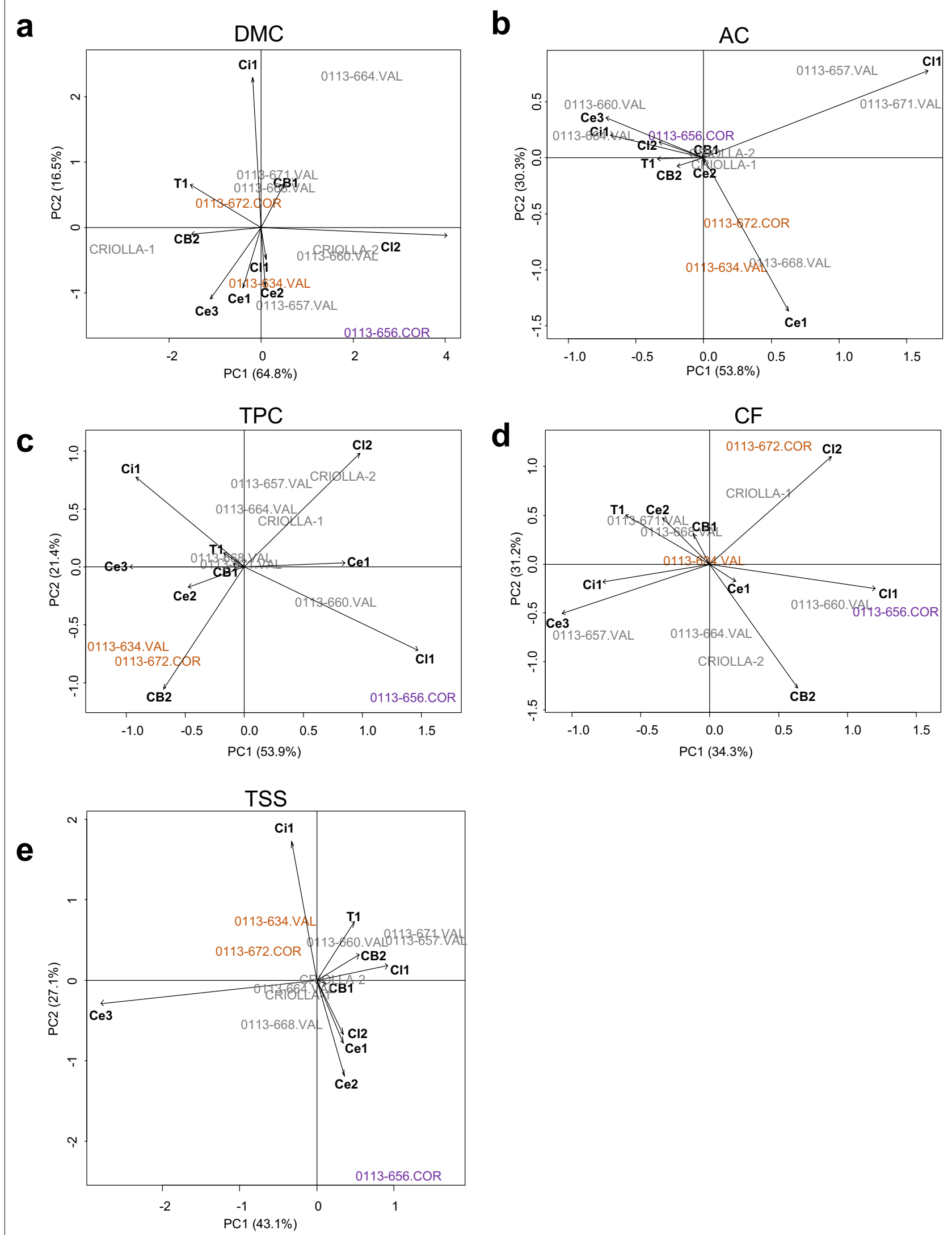
protein content $(>4.85 \%)$ and $\beta$-carotenes. The creamywhite or pale-yellow colors are due to the amount of carotenoid in the storage root. The attractive purple color is due to a high percentage of proteins and fibers, and its pigment is related to high levels of anthocyanin, which has antioxidant properties [24]. Similarly to this study, high contents of ash and crude fiber were previously found in yellow and orange-fleshed varieties [10]. The moderate proportion of protein is a valuable nutritional factor in the pigmented genotypes due to its contribution of essential amino acids, which makes its flour appreciated to be used as a complement to cereal flours that have small amounts of that amino acid. Purple genotypes showed the highest TSS content, and no major relation to flesh color was observed in accordance with previous studies $[8,51]$.

In addition to genotypic diversity, this study showed a large difference in the chemical composition of sweetpotato according to its maturity state, climatic conditions, soil type, and location. The proximate composition of sweetpotato storage roots was a phenotypic trait with wide plasticity concerning harvest time. White-cream fleshed genotypes maintained or increased their high DMC through time and induced a reduction in the proportion of accumulated AC and TPC. Therefore, high energetic and less nutritive roots are obtained at the late harvest. In pigmented genotypes (yellow, orange, and purple), DMC was stable or increased up to 120 DAP; these genotypes showed stability in AC and TPC, and only their TSS exhibited an increase through time. In pigmented genotypes, their nutritional quality was preserved.

Physiologically, DMC is associated with the ability of roots to attract photoassimilates from leaves [40]; however, it is a quality trait that could be highly influenced by several factors such as the genotype, geographic area, amount of light, root flesh color and storage conditions $[20,25,29,48,53,56]$. Although reports show that DMC increases up to 150 DAP [43], the results in this study suggest that DMC was affected by the harvest period independently in each genotype. Further, orange-fleshed genotypes used in this study showed consistent response as previously reported [32]. As soon as the roots became physiologically mature $(120$ DAP), reduction in DMC occurs, probably associated with reallocation for shoot growth. DMC is a parameter associated with starch content, and it is an important quality parameter in fresh consumption and also when it is used to elaborate various food products, such as preformed foods, restructured frying using a gelling system from mashed potato and sweetpotato flour, snacks, and spaghetti [37, 6]. Then, the desired DMC value should be obtained according to its final use, and it would depend on the genotype, but also the growing conditions of the crop.

In general, significant reductions in $\mathrm{AC}, \mathrm{TPC}$, and $\mathrm{CF}$ were observed after 120 DAP, demonstrating that food quality is affected under extended harvest periods similar to what has been found in cassava where a significant reduction in protein content and minerals was observed from harvest at 7 to 12 months [31]. Conversely, a significant increase of TSS was observed in a study with eight genotypes, demonstrating that late harvesting in some genotypes improves the content of TSS as previously reported by Tavares et al. [46].

Consistently, DMC was differentially affected by environmental conditions, lower temperatures, and limited water availability that promoted its accumulation [20]. Environmental differences observed among locations could explain the response in the proximal composition of the evaluated genotypes, where the Codazzi location showed an alkaline $\mathrm{pH}$, which is associated with lower $\mathrm{P}$ and micronutrient solubility; therefore, the proximal composition was affected. In contrast, Cerete and Carmen B showed neutral $\mathrm{pH}$ and higher organic matter, guaranteeing major nutrient availability in the soils. However, rain events and temperature could be the environmental factors that could have influenced crop growing conditions directly. The abundance of organic matter and micronutrients in soils of Cerete and Carmen B influenced a higher accumulation of AC and TPC positively, and the higher nutrient availability in soils promoted better nutritional quality in storage roots, as previously reported in fertilizer applications in various studies [1, $13,50]$. In those locations, water availability and soil texture directly influenced the $\mathrm{pH}$ and nutrient availability [26, 27]. Consistently, dry conditions improved TSS due to high solar radiation availability, which increases photoassimilates, and apparently, drainage efficiency [46].

The AMMI analysis was used to understand the effect of environment, genotype, and their interaction $(\mathrm{GxE})$; the environment and the genotype showed a significant contribution to the total variance. The effect of the environment was higher compared to the genotype for the parameters TPC, AC, CF, and TSS. DMC was most influenced by the genotype, followed by the environment. These results are consistent with previous reports that showed a significant contribution of the genotype, the environment, and the interaction of both (GxE), as well as a high environmental contribution in DMC [11] and TPC [49]. Although the magnitude of the GxE interaction was not significant, the environment strongly influenced the proximate composition; therefore, the selection for these traits could be made in early breeding stages [48]. 


\section{Conclusions}

The high diversity found in the evaluated sweetpotato genotypes for food quality demonstrated the richness of this crop and the potential of each genotype. R, G, and $B$ pixel values and the proximate composition were successfully used as viable tools to characterize phenotypic and compositional features, as well as their relationship to establish food quality in sweetpotato. Furthermore, harvest time affected the proximate composition in sweetpotato, thus determining the appropriate harvest period to improve the nutritional quality of the final product. White-cream fleshed genotypes maintained or increased their DMC as harvest time increased, representing an opportunity for the starch or flour industry. Yellow-orange and purple-fleshed genotypes showed high and/or stable AC, TPC, and CF levels. Thus, the consumption of these genotypes with pigmented flesh due to their better proximate composition that reflects a high nutritional quality, should be recognized and used integrally to improve the quality of a diet. Environmental conditions are important factors, so they should be considered for improving the quality parameter when producing sweetpotato; moreover, according to the findings of this study, the presence of pre-harvest rain promotes DMC translocation and loss. On the contrary, TPC, AC, and CF can be kept stable or even increased, except in environments with high temperatures that induce low accumulation.

\section{Methods}

\section{Plant material}

Twenty sweetpotato genotypes included in the working collection of Agrosavia were evaluated in this study. Although there is evidence of some genotypes being introductions from other countries, all the genotypes were collected in farms of sweetpotato producers. The genotypes included in this study were the following: 0113-634.VAL, 0113-656.COR, 0113-657.VAL, 0113658.COR, 0113-659.VAL, 0113-660.VAL, 0113-662.VAL, 0113-663.VAL, 0113-664.VAL, 0113-665.VAL, 0113-666. VAL， 0113-668.VAL， 0113-669.VAL， 0113-670.VAL, 0113-671.VAL, 0113-672.COR, 0113-673.VAL and 0113674.VAL. Furthermore, the genotypes Criolla and Criolla $\mathrm{V}$ were used as local checks.

\section{Study site and growth conditions}

The selected sweetpotato genotypes were established in six localities in dry and wetland zones in the Caribbean region of Colombia, as follows: Cerete, Carmen de Bolivar (Carmen B), Agustin Codazzi (Codazzi), Corozal, Tolu, and Riohacha. The crop cycles evaluated were 2015 and 2016.
The description of the environmental conditions, such as average temperature, rainfall, and edaphic conditions found in the study site, is presented in Table 8 . The soils of the study site showed sandy-to-clay textures, and the physicochemical characteristics are also found in Table 8.

\section{Experimental design}

The genotypes were established following two experimental conditions, uniform yield test (UYT) and agronomic evaluation test (AET), that comprised 26 and 52 plants, respectively. A randomized complete block design (RCBD) was used in this study, with three or four repetitions per site and a density of 25.000 plants/ha was used (1.0 $\mathrm{m}$ between rows $\times 0.4 \mathrm{~m}$ between plants).

\section{Images and color estimation}

Root flesh color was measured by red (R), green (G), and blue (B) (RGB) imaging using a Canon EOS 600D camera configured at a similar depth and sensitivity (sensor) settings for all genotypes. Light, time of exposure, and distance between the specimens and the camera were controlled entirely among the genotypes assessed.

\section{Total soluble solids}

Total soluble solids (TSS) were measured with a digital refractometer using a scale from 0 to $32 \pm 0.2{ }^{\circ}$ Brix equipped with automatic temperature compensation. The refractive index was established in juice from several sweetpotato root flesh samples, which were grated and extracted by compression.

\section{Bromatologic test description}

For the bromatological assessment, about $200 \mathrm{~g}$ of roots were sampled per replicate; root slices were dried in an oven at $60 \pm 5^{\circ} \mathrm{C}$ for $72 \mathrm{~h}$. Dry matter content (DMC) was established from the fresh and dry weights of the sample. The crude protein content (TPC) was determined by the Kjeldahl distillation unit (semi-micro) method according to the AOAC 960.52 protocol (Association of Official Analytical Chemists [5]), expressing the values in percentage of dry matter. Crude fiber (CF) was extracted by acid hydrolysis according to the ISO 6865 method and determined by filtration. Ash content (AC) was measured by burning the material in an oven at $550-660{ }^{\circ} \mathrm{C}$, according to the AOAC 942.05 method, and expressed as a percentage of dry matter (AOAC, 1990).

\section{Data analysis}

$R, G$, and B pixel values were used to determine the diversity in the genotypes evaluated through hierarchical analysis employing the hclust function and the agglomeration UPMGA method using the ape library 
Table 8 Study site and soil fertility characteristics

\begin{tabular}{|c|c|c|c|c|c|c|c|}
\hline Characteristics & Units & Corozal & Codazzi & Cerete & Carmen B & Tolu & Riohacha \\
\hline Coordinates & & $\begin{array}{l}9^{\prime \prime} 17^{\prime} 34.38^{\prime \prime \prime} \mathrm{N} \\
7^{\prime \prime \circ} 20^{\prime} 9.00^{\prime} \\
W\end{array}$ & $\begin{array}{l}1^{\prime \prime \prime} 00^{\prime} 01.2^{\prime \prime \prime} \mathrm{N} \\
7^{\prime \prime \prime} 15^{\prime} 22.4^{\prime} \\
W\end{array}$ & $\begin{array}{l}8^{\prime \prime} 50^{\prime} 27.47^{\prime \prime \prime} \mathrm{N} \\
75^{\prime \prime} 48^{\prime} 27.5^{\prime \prime \prime} \\
\mathrm{W}\end{array}$ & $\begin{array}{l}" \circ 42^{\prime} 50.8^{\prime \prime \prime} \mathrm{N} \\
7^{\prime \prime} 06^{\prime} 26.9^{\prime} \mathrm{W}\end{array}$ & $\begin{array}{l}{ }^{\prime \prime} 29^{\prime} 21.6^{\prime \prime}, 07^{\prime \prime} 34^{\prime} 12.9^{\prime} \\
\text { W }\end{array}$ & $\begin{array}{l}11^{\prime \prime} 07^{\prime} 15.05^{\prime \prime \prime} \mathrm{N} \\
72^{\prime \prime} 59^{\prime} 22.87^{\prime \prime} \\
W\end{array}$ \\
\hline Landscape & & Plains & Foothills & Plains & $\begin{array}{l}\text { Mountains and } \\
\text { foothills }\end{array}$ & Hills and valley & Hills \\
\hline Mean temperature & $\left({ }^{\circ} \mathrm{C}\right)$ & 26.9 & 28.1 & 27.7 & 26.9 & 27.6 & 28.3 \\
\hline Annual rainfall & $(\mathrm{mm})$ & 1,127 & 1,560 & 1,264 & 1,179 & 1,129 & 588 \\
\hline Soil texture & & Sandy-loam & Sandy-loam & Clayey & Clay-loam & Sandy & Sandy \\
\hline \multicolumn{8}{|l|}{ Soil characteristics: } \\
\hline $\mathrm{pH}$ & & 7.21 & 7.84 & 6.99 & 7.18 & 6.03 & 6.71 \\
\hline $\mathrm{OM}$ & $\%$ & 1.31 & 1.66 & 2.87 & 2.55 & 3.07 & 1.22 \\
\hline P & $\mathrm{mg} / \mathrm{kg}$ & 15.78 & 150.30 & 10.09 & 28.83 & 20.38 & 29.83 \\
\hline S & $\mathrm{mg} / \mathrm{kg}$ & 3.32 & 4.17 & 8.77 & 2.32 & 6.2 & 17.57 \\
\hline $\mathrm{Ca}$ & $\mathrm{cmol}(+) / \mathrm{kg}$ & 17.29 & 13.04 & 14.79 & 21.74 & 18.68 & 9.68 \\
\hline $\mathrm{Mg}$ & $\mathrm{cmol}(+) / \mathrm{kg}$ & 5.77 & 1.14 & 6.11 & 6.69 & 8.81 & 2.40 \\
\hline K & $\mathrm{cmol}(+) / \mathrm{kg}$ & 0.30 & 0.31 & 0.50 & 0.20 & 0.92 & 0.24 \\
\hline $\mathrm{Na}$ & $\mathrm{cmol}(+) / \mathrm{kg}$ & 0.40 & 0.32 & 0.20 & 0.29 & 2.18 & 0.80 \\
\hline CEC & $\mathrm{cmol}(+) / \mathrm{kg}$ & 23.76 & 14.80 & 21.59 & 28.92 & 30.59 & 13.14 \\
\hline EC & $\mathrm{dS} / \mathrm{m}$ & 0.19 & 0.61 & 0.92 & 0.20 & 0.3 & 0.92 \\
\hline $\mathrm{Fe}_{\mathrm{av}}$ & $\mathrm{mg} / \mathrm{kg}$ & 13.20 & 27.19 & 44.16 & 46.15 & 77.05 & 31.77 \\
\hline $\mathrm{Cu}_{\mathrm{av}}$ & $\mathrm{mg} / \mathrm{kg}$ & 1.28 & 2.87 & 5.90 & 1.29 & 3.15 & 1.29 \\
\hline $\mathrm{Mn}_{\mathrm{av}}$ & $\mathrm{mg} / \mathrm{kg}$ & $<1.00$ & 3.20 & $<1.00$ & 13.22 & 16.82 & 2.96 \\
\hline$Z n_{a v}$ & $\mathrm{mg} / \mathrm{kg}$ & $<1.00$ & 1.28 & 1.04 & 1.20 & 3.08 & 1.32 \\
\hline $\mathrm{B}_{\mathrm{av}}$ & $\mathrm{mg} / \mathrm{kg}$ & 0.23 & 0.21 & 0.27 & 0.51 & 0.26 & 0.49 \\
\hline Harvest period (year) & & $\begin{array}{l}2015 \\
2016\end{array}$ & $\begin{array}{l}2015 \\
2016\end{array}$ & $\begin{array}{l}2015 A \\
2015 B \\
2016\end{array}$ & $\begin{array}{l}2015 \\
2016\end{array}$ & 2016 & 2015 \\
\hline
\end{tabular}

${ }^{*} \mathrm{pH}$ water: soil 2.5:1.0, organic matter (OM), phosphorus (P) Bray II, sulfur (S) monocalcium phosphate, calcium (Ca), magnesium (Mg), potassium (K), and sodium (Na), cation exchange capacity (CEC), electric conductivity (EC) 2.5:1.0 relation, available iron (Fe), copper (Cu), manganese (Mn), zinc ( $\mathrm{Zn}$ ) and boron (B)

[34]. The heatmap was elaborated using the ggplot2 library [52]. A joint analysis of variance was used to test the effects of the genotype (G) and the environment $(E)$, as well as the magnitude of the $G \times E$ interaction. The AMMI analysis was used to determine the main or additive genotype and environmental effects, and the multiplicative effects for the $\mathrm{G} \times \mathrm{E}$ interaction in selected genotypes from the G1, G2 and G3 groups (six genotypes with cream-white flesh, two with orange flesh, and one with purple flesh were selected, respectively). Tukey's multiple comparison test was used for the mean comparison test between genotypes, locations, and harvest times $(\alpha=0.05)$. R software (version 3.4.0) was used for the analyses.

\section{Supplementary information}

Supplementary information accompanies this paper at https://doi. org/10.1186/s40066-020-00268-4.
Additional file 1: Table S1. Mean square values obtained through the variance component analysis for selected quality traits among 20 sweetpotato genotypes at different harvest times.

\section{Abbreviations}

AC: Ash content; AMMI: Additive main effects and multiplicative interaction; B: Blue; CF: Crude fiber; DAP: Days after planting; DMC: Dry matter content; G: Green; R: Red; TPC: Total protein content; TSS: Total soluble solids.

\section{Acknowledgements}

We thank Oswaldo Martinez and Manuel Hernandez for their valuable technical support.

\section{Authors' contributions}

AR and IP designed the experiments; JP, RM, JM, LE, IP, CS, AR, and JM performed the experiments and wrote the manuscript; AR and LG analyzed the data; IP, CS, CDP, LG, and AR wrote the manuscript. All authors have read and approved the manuscript.

\section{Funding}

This study was funded by Ministerio de Agricultura y Desarrollo Rural (MADR) of Colombia [Agreement No. 000023-2015 (TV16)]. The funding agency had no part in the study design, data collection, and analysis, interpretation, the decision to publish, or preparation of the manuscript. 


\section{Availability of data and materials}

The datasets used and/or analyzed during the current study are available from the corresponding author on reasonable request.

\section{Ethics approval and consent to participate}

Not applicable.

\section{Consent for publication}

Not applicable.

\section{Competing interests}

The authors declare that they have no competing interests.

\section{Author details}

${ }^{1}$ Corporación Colombiana de Investigación Agropecuaria - AGROSAVIA Centro de Investigación Turipaná, Km 13 vía Montería, Cereté, Colombia. ${ }^{2}$ Department of Crop Science, Breeding and Plant Medicine, Mendel University in Brno, Zemedelska 1, Brno, Czech Republic. ${ }^{3}$ Department of Food Engineering, Universidad de Cordoba, Km 1 Cereté - Ciénaga de Oro, Berastegui, Colombia.

Received: 2 April 2020 Accepted: 19 September 2020

Published online: 21 October 2020

\section{References}

1. Agbede TM. Tillage and fertilizer effects on some soil properties, leaf nutrient concentrations, growth and sweet potato yield on an Alfisol in southwest Nigeria. Soil Till Res. 2010;110:25-32.

2. Alam MK, Rana ZH, Islam SN. Comparison of the proximate composition, total carotenoids and total polyphenol content of nine orange-fleshed sweet potato varieties grown in Bangladesh. Foods. 2016;5(3):64. https:// doi.org/10.3390/foods5030064.

3. Ames T, Smith N, Braun A, O'Sullivan J, Skoglund L. Sweetpotato: major pests, diseases, and nutritional disorders. Lima: International Potato Center (CIP). 1997

4. An LV, FrankowLindberg BE, Lindberg JE. Effect of harvesting interval on defoliation and yield and chemical composition on leaves, stems and tubers of sweet potato (Ipomea batatas L. (Lam)) plant parts. Field Crop Res. 2003:82:49-58.

5. Association of Official Analytical Chemists. Official Method of Analysis $N^{\circ}$ 942.05, 960.15 th ed. Arlington. 1990

6. Aviléz YD, De Paula CD, Pastrana YI. Sensorial and physicochemical characterization of a restructured fried sweet potato (Ipomoea batatas L.) using a gelation system. Adv J Food Sci Technol. 2018;16:29-34.

7. Baafi E, Gracen V, ManuAduening J, Blay E, Ofori K, Carey E. Genetic control of dry matter, starch and sugar content in sweetpotato. Acta Agr Scand B. 2017;67(2):110-8.

8. Caetano PK, De Mariano-Nasser Fa C, Mendonça VZ, Furlaneto KA, Daiuto ER, Vieites RL. Physicochemical and sensory characteristics of sweet potato chips undergoing different cooking methods. Food Sci Technol. 2018;38(3):434-40.

9. Cho SA, Yoo B. Comparison of the effect of sugars on the viscoelastic properties of sweet potato starch pastes. Int J Food Sci Technol. 2010;45:410-4.

10. Dako E, Retta N, Desse G. Comparison of three sweet potato (Ipomoea batatas (L) Lam) varieties on nutritional and anti-nutritional factors. Glob J Sci Front Res. 2016;16(4):63-72.

11. Ekanayake I, Collins W. Effect of irrigation on sweet potato root carbohydrates and nitrogenous compounds. J Food Agric Environ. 2004;2(1):243-8.

12. Eyarkai-Nambi VE, Thangavel K, Shahir A, Thirupathi V. Comparison of various $R G B$ image features for nondestructive prediction of ripening quality of "Alphonso" mangoes for easy adoptability in machine vision applications: a multivariate approach. J Food Quality. 2016;39(6):816-25

13. Gichuhi PN, Kpomblekou AK, Bovell-Benjamin AC. Nutritional and physical properties of organic Beauregard sweet potato [Ipomoea batatas (L.)] as influenced by broiler litter application rate. J Food Sci Nutr. 2014;2:332-40.
14. Ginting E, Yulifianti R, Jusuf M. Selected orange-fleshed sweet potato genotypes with high dry matter and beta-carotene contents. Acta Hortic. 2017:1152:367-74.

15. González A, Alvis A, Arrázola G. Efecto del recubrimiento comestible en las propiedades de trozos de batata (Ipomoea batatas Lam) fritos por inmersión. Parte 1: Textura Inf Tecnológica. 2015;26(1):95-102.

16. Granda L, Rosero A, Benešova K, Pluháčková H, Neuwirthová J, Cerkal R. Content of selected vitamins and antioxidants in colored and nonpigmented varieties of quinoa, barley, and wheat grains. J Food Sci. 2018;83(10):2439-47

17. Grüneberg,WJD, Mwanga ROM, Carey EE, Huamani K, Diaz F, et al. Advances in sweetpotato breeding from, U.K: CAB International. 2015. p. 3-68.

18. Gurmu F, Hussein S, Laing M. Evaluation of candidate orangefleshed sweetpotato clones for nutritional traits. Acta Agr Scand B. 2017:67(7):651-9.

19. Iqbal SM, Gopal A, Sankaranarayanan PE, Nair AB. Classification of selected citrus fruits based on color using machine vision system. Int J Food Prop. 2015;19(2):272-88.

20. Kathabwalika DM, Chilembwe EHC, Mwal VM. Evaluation of dry matter, starch and beta-carotene content in orange-fleshed sweet potato (Ipomoea batatas L) genotypes tested in three agro-ecological zones of Malawi. African J Food Sci. 2016;10(11):320-6.

21. Kaur H, Sawhney BK, Jawandha SK. Evaluation of plum fruit maturity by image processing techniques. J Food Sci Technol. 2018;55(8):3008-15.

22. Kendal D, Hauser CE, Garrard GE, Jellinek S, Giljohann KM, Moore JL. Quantifying plant colour and colour difference as perceived by humans using digital images. PLoS ONE. 2013;8(8):e72296.

23. Lebot V. Sweet Potato. In: Bradshaw JE, editor.Handbook of plant breeding, Root and Tuber Crops. United Kingdom: Springer; 2010. p. 97-126.

24. Low J, Mwanga R, Andrade M, Carey E, Ball A. Tackling vitamin A deficiency with biofortified sweetpotato in sub-Saharan Africa. Glob Food Sec. 2017;14:23-30.

25. Mbah EU, Eke-Okoro O. Relationship between some growth parameters, dry matter content and yield of some sweet potato genotypes grown under rainfed weathered ultisols in the humid tropics. J Agron. 2015;14(3):121-9.

26. Misra A, Tyler G. Effect of soil moisture on soil solution chemistry, biomass production, and shoot nutrients in two native grasses on a calcareous soil. Commun Soil Sci Plan. 2000:31:2727-38.

27. Misra A, Tyler G. Influence of soil moisture on soil solution chemistry and concentrations of minerals in the calcicoles Phleum phleoides and Veronica spicata grown on a limestone soil. Ann Bot. 1999;84:401-10.

28. Musabyemungu A, Wasswa P, Alajo A, Chelagat D, Otema M, Musana P, Rukundo P, Gibson P, Edema R, Pecota K, Yencho C, Yada B. Adaptability of a US purple-fleshed sweetpotato breeding population in Uganda. Aust J Crop Sci. 2019;13:17-25.

29. Nair AGH, Vidya P, Ambu V, Sreekumar J, Mohan C. Evaluation of orange fleshed sweet potato genotypes for storage root yield and dry matter content. Int J Appl Pure Sci Agric. 2017;03(9):83-5.

30. Neela S, Fanta SW. Review on nutritional composition of orange-fleshed sweet potato and its role in management of vitamin A deficiency. Food Sci Nutr. 2019;7(6):1920-45.

31. Oluwaniyi O, Oladipo J. Comparative studies on the phytochemicals, nutrients and antinutrients content of cassava varieties. J Turkish Chem Soc. 2017:4(3):661-74

32. Onyemachi VC, Anyemachi SE, Kalu CE, Nnam RE, Chigbo DC. The effect of maturity on proximate composition of orange fleshed sweet potato. Ann Food Sci Technol. 2018;19(1):87-91.

33. Panja P, Sharma A, Singh B. Studies on Physico-chemical constituents in different cultivars of sweet potato under West Bengal condition. Int J Environ Agric Biotech. 2016;9(6):979-85.

34. Paradis E, Schliep K. ape 50: an environment for modern phylogenetics and evolutionary analyses in. Bioinformatics. 2018. https://doi. org/10.1093/bioinformatics/bty633.

35. Rahman SM, Wheatley C, Rakshit S. Selection of sweet potato variety for high starch extraction. Inter J Food Prop. 2003;6(3):419-30.

36. Ravi V, Aked J, Balagopalan C. Review on tropical root and tuber crops I Storage methods and quality changes. Crit Rev Food Sci Nutr. 1996;36:661-709. 
37. Renjusha M, Pagmaja G, Sajeew M. Comparative effect of edible gums and dietary fibers on the cooking, starch digestibility and ultrastructural characteristics of sweet potato spaghetti. Inter J Food Prop. 2014;47:68-76.

38. Reynolds LB, Rosa N, McKeown AW. Effects of harvest date on certain chemical and physical characteristics of sweet potato grown in southwestern Ontario. Can J Plant Sci. 1994;74:603-6.

39. Rossell G, Reynoso D, Espinosa C, Manrique I, Panta A, Roca W. The sweetpotato germplasm collection at CIP, Lima-Peru. Paper presented in the CIP-UPWARD Workshop "Sweetpotato Global Conservation Strategy. The Global Crop Diversity Trust. Manila, Philippines, 30 April-2 May 2007

40. Rukundo P, Shimelis $H$, Laing M, Gahakwa D. Storage root formation, dry matter synthesis, accumulation and genetics in sweet potato. Aust J Crop Sci. 2013;13:2054-6.

41. Sajilata MG, Singhal RS. Speciality starches for snack foods. Carbohyd Polym. 2005;59:131-51.

42. Seem RC. The measurement and analysis of the effects of crop development on epidemics. In: Kranz J, Rotem J, editors. Experimental techniques in plant disease epidemiology. Berlin: Springer; 1988. p. 51-67.

43. Shigwedha M. Determination of the appropriate duration of sweet potato varieties to mature. Agricola. 2012;22:50-2.

44. Suda I, Oki T, Masuda M, Kobayashi M, Nishiba Y, Furuta S. Physiological functionality of purple-fleshed sweet potatoes containing anthocyanins and their utilization in foods. JARQ-Jpn Agr Res Q. 2003;37(3):167-73.

45. Tang Y, Cai W, Xu B. Profiles of phenolics, carotenoids and antioxidative capacities of thermal processed white, yellow, orange and purple sweet potatoes grown in Guilin China. Food Sci Hum Wellness. 2015;4:123-32.

46. Tavares JR, Paula RM, Vieira L, Silva GB, Lins AN, Barros AP, Cabral E, Dantas PC, Nascimento A. Quality of sweet potato cultivars planted harvested at different times of two seasons. Aust J Crop Sci. 2018;16(6):898-904.

47. Tomlins K, Owori C, Bechoff A, Menya G, Westb A. Relationship among the carotenoid content, dry matter content and sensory attributes of sweet potato. Food Chem. 2012;131:14-21.

48. Tumwegamire S, Kapinga R, Rubaihayo PR, LaBonte DR, Grüneberg WJ, Burgos G, Felde TZ, Carpio R, Pawelzik E, Mwanga ROM. Evaluation of dry matter, protein, starch, sucrose, b-carotene, iron, zinc, calcium, and magnesium in east African sweetpotato [Ipomoea batatas (L.) Lam] Germplasm. Hortic Sci. 2011;46(3):348-57.

49. Tumwegamire S, Rubaihayo PR, Grüneberg WJ, La Bonte DR, Mwanga ROM, Kapinga R. Genotype environment interactions for east African orange-fleshed sweetpotato clones evaluated across varying ecogeographic conditions in Uganda. Crop Sci. 2016;56(4):1628-44.

50. Ukom AN, Ojimelukwe PC, Okpara DA. Nutrient Composition of selected sweet potato [Ipomoea batatas $(\mathrm{L}) \mathrm{Lam}$ ] varieties as influenced by different levels of nitrogen fertilizer application. Pakistan J Nutr. 2009;8(11):1791-5.

51. Vizzotto M, dos Santos Pereira E, Rocha J, Cardoso P, Lettnin NM, Suita LA, Richter AC. Physicochemical and antioxidant capacity analysis of colored sweet potato genotypes: in natura and thermally processed. Cienc Rural. 2017;47(4):1-8.

52. Wickham H. ggplot2: Elegant Graphics for Data Analysis. New York: Springer-Verlag; 2016

53. Woolfe AJ. Sweet Potato: An Untapped Food Resource. 2nd ed. New York: Cambridge University Press; 2008.

54. Yildirim Z, Tokuşoğlu O, Öztürk G. Determination of sweetpotato [/pomoea batatas $(\mathrm{L}) \mathrm{Lam}$ ] genotypes suitable to the Aegean region of Turkey. Turk J Field Crops. 2011;16(1):48-53.

55. Zhang L, Zhao L, Bian X, Guo K, Zhou L, Wei C. Characterization and comparative study of starches from seven purple sweet potatoes. Food Hydrocolloid. 2018;80:168-76.

56. Zhang Z, Wheatley $\mathrm{C}$, Corke H. Biochemical changes during storage of sweet potato roots differing in dry matter content. Postharvest Biol Tec. 2002;24(3):317-25.

\section{Publisher's Note}

Springer Nature remains neutral with regard to jurisdictional claims in published maps and institutional affiliations.
Ready to submit your research? Choose BMC and benefit from:

- fast, convenient online submission

- thorough peer review by experienced researchers in your field

- rapid publication on acceptance

- support for research data, including large and complex data types

- gold Open Access which fosters wider collaboration and increased citations

- maximum visibility for your research: over $100 \mathrm{M}$ website views per year

At $\mathrm{BMC}$, research is always in progress.

Learn more biomedcentral.com/submissions 